$1-1-1967$

\title{
Experimental control of insect pests of alfalfa in West Virginia, other than the alfalfa weevil, 1959-1964
}

\author{
C. K. Dorsey
}

Follow this and additional works at: https://researchrepository.wvu.edu/ wv_agricultural_and_forestry_experiment_station_bulletins

\section{Digital Commons Citation}

Dorsey, C. K., "Experimental control of insect pests of alfalfa in West Virginia, other than the alfalfa weevil, 1959-1964" (1967). West Virginia Agricultural and Forestry Experiment Station Bulletins. 549T.

https://researchrepository.wvu.edu/wv_agricultural_and_forestry_experiment_station_bulletins/669 @ WVU. It has been accepted for inclusion in West Virginia Agricultural and Forestry Experiment Station Bulletins by an authorized administrator of The Research Repository @ WVU. For more information, please contact ian.harmon@mail.wvu.edu. 
West Virginia University Libraries

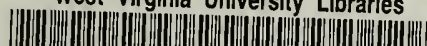



West Virginia University gricultural Experiment Station
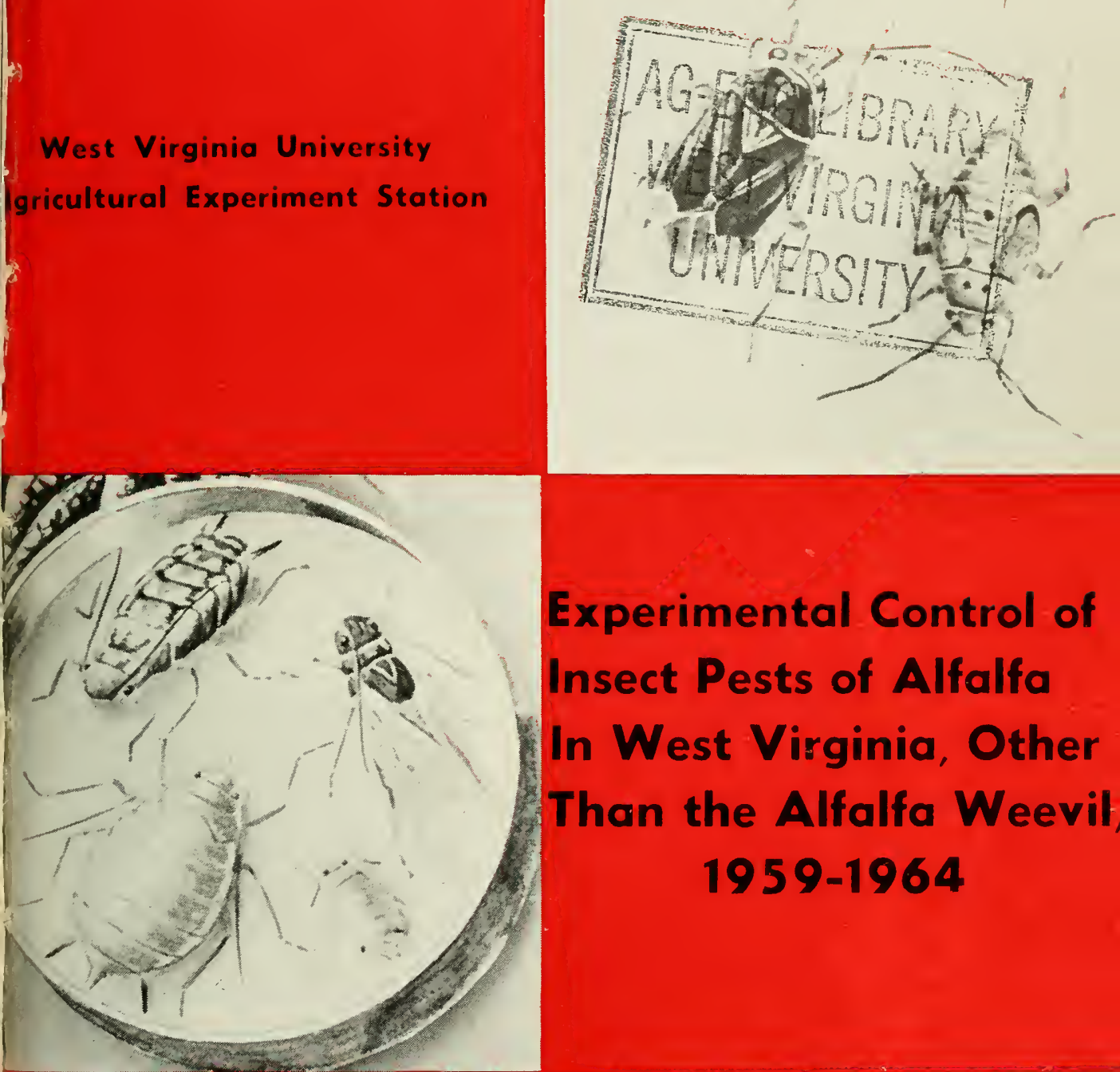

\section{Experimental Control of}

Insect Pests of Alfalfa In West Virginia, Other Than the Alfalfa Weevil, 1959-1964

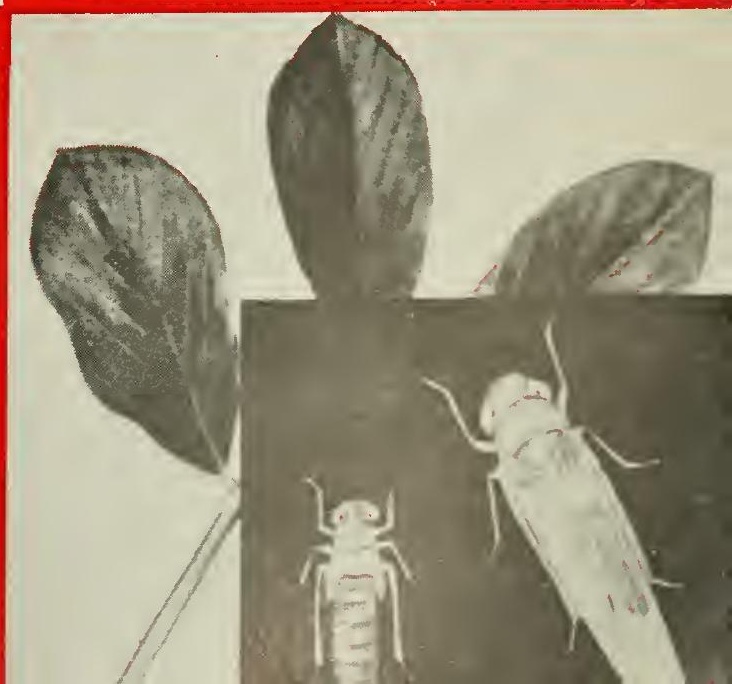





\title{
Experimental Control of Insect Pests Of Alfalfa in West Virginia, Other Than the Alfalfa Weevil, 1959-1964
}

\author{
C. K. DORSEY
}

\section{West Virginia University Agricultural Experiment Station} A. H. VanLandingham, Director Morgantown 


\section{The Author}

C. K. Dorsey is Agricultural Experiment Station Entomologist.

\section{Acknowledgments}

The author appreciates the help of Dr. A. E. Drake, former director of the Computer Center, West Virginia University, for his assistance in the planning of experiments and the statistical evaluation of the results.

\section{SUMMARY}

Various spray and granular formulations of 42 insecticides were applied on alfalfa plots for insect control effectiveness evaluations during the period of experimental tests (1959-64 inclusive).

All sprays were applied with high pressure, high volume, hydraulic sprayers $(20 \mathrm{ft}$. boom). The granules were applied with cyclone-type seeders (power and hand-operated).

In leafhopper control, malathion, dimethoate, diazinon, and azinphosmethyl (Guthion®) sprays gave the best results for spring and summer treatments. The only treatment applied in the fall (October) which produced economic control the following spring was granular methylethyl azinphosmethyl.

Plant bugs were controlled best with malathion sprays. Effective results also were obtained with Zinophos@ (cynem) 0,0-dimethyl 0-2-pyrazinyl phosphorothioate, Tiguvon ${ }^{\circledR}$ (fenthion) 0,0-Dimethyl 0-[4-(methylthio )-m-toly1] phosphorothioate, Ciodrin ${ }^{\circledR}$ alpha-methyl benzyl 3-hydroxycrotonate dimethyl phosphate, and Dylox® (trichlorfon) dimethyl 2,2,2-trichloro-1-hydroxy-ethyl phosphonate sprays.

The most satisfactory aphid control resulted from the use of sprays of Zectran ${ }^{\circledR}$ 4-dimethyl amine-3-5-xylyl methylcarbamate, and American Cyanamid 47470 cyclic propylene (dithoxyphosphinyl) dithioimidocarbonate.

In spring treatments spittlebug populations were reduced best with Thiodan® $(6,7,8,9,10,10$-hexachlor-1,5,5a,6,9,9a-hexahydro-6,9-methano-2: 4,3-benzodioxathiepin-3-oxide), Tiguvon ${ }^{\circledR}$, Zectran ${ }^{\circledR}$, and c a r b a ry ] sprays. None of these, however, gave good economic control. 


\section{Experimental Control of Insect Pests Of Alfalfa in West Virginia, Other Than the Alfalfa Weevil, 1959-1964}

\section{K. DORSEY}

THOUGH the alfalfa weevil, Hypera postica (Gyllenhal) is at the

1 present time the most destructive insect pest of alfalfa in the State, there are several other kinds of insects which are of economic importance to alfalfa production in West Virginia.

Included in this group are representatives from the orders Homoptera (leafhoppers, aphids, and spittlebugs) and Hemiptera (plant bugs). These pests also cause economic damage to alfalfa by sucking vital juices from the plants. Mittler and Sylvester (1961) were of the opinion that the actual fluid and nutrient drain imposed upon alfalfa plants by heavy aphid feeding may be largely responsible for the severe injury which they cause. A number of workers have emphasized the importance of damage of this nature.

The observations of Wilson et al. (1959) indicate that alfalfa production can be reduced by meadow spittlebug attack as much as one ton per acre when they are numerous ( 40 or more per stem). Weaver and Hibbs (1952) also found that spittlebug attacks on alfalfa and red clover reduced the yield per acre ( $1 / 2$ to 1 ton). They also reported that the protein content of alfalfa was somewhat higher ( 0.2 to 1.7 per cent) in plants from insecticidally treated fields. Carotenoids were increased from $3-37 \mathrm{mg} / \mathrm{gm}$ of dry matter in alfalfa and $4-22 \mathrm{mg} / \mathrm{gm}$ in red clover following treatment for spittlebug control.

Stitt (1948) found that leafhoppers and plant bugs reduced vegetative growth of alfalfa during the period of June to September as much as 72.0 per cent and 56.0 per cent, respectively. Medler (1958) observed that alfalfa plants attacked by sucking insects had shorter internodes and reduced stem length. A reduction of alfalfa hay production of 17.5 per cent in alfalfa infested with plant bugs was reported by Shull et al. (1934). They also observed experimentally that 98.0 per cent more seed pods were produced by caged plants free from plant bug attack. Romney et al. (1945) found that Lygus bugs reduced the weight and viability of guayule seed. The number of filled seeds from protected plants was three to four times greater than seeds from unprotected plants. MacCollom (1958) pointed out that several species of plant bugs were especially destructive on birdsfoot trefoil during bud development and bloom 
Wilson et al. (1955) determined that alfalfa recovered more rapidly following cutting in fields where leafhoppers had been controlled (nine varieties averaged 45.0 per cent more growth two weeks after cutting). They also observed that alfalfa in fields treated for leafhopper control one year showed an earlier growth response and an increased yield the following year (nine varieties average 18.0 per cent more growth and the first cutting produced one-third ton more per acre). The influence of leafhoppers on yield and chemical composition of alfalfa hay was also studied by Smith and Medler (1959). They found that the percentage of protein, ash, calcium, and phosphorus, all important constituents in animal production, was reduced by leafhopper attacks 33.0-38.0 per cent under high fertility conditions and 41.0-55.0 per cent under low fertility conditions. Alfalfa yield was reduced 21.0-28.0 per cent (high fertility) and 36.0-48.0 per cent (low fertility) in untreated fields.

In areas where alfalfa and clover seed are produced, sucking insects (leafhoppers, plant bugs, spittlebugs, aphids, and others) have a very important effect on the quality and quantity of seed produced. Schull and Medler (1947), Medler and Schull (1947), Medler and Chamberlin (1948), Drake (1948), Daniels (1955), Medler and Brooks (1957), and Medler (1958) have all reported the serious damage caused to seed production by these insects. Medler and Schull (1947) for example, observed that there was an increased yield of seeds in treated fields from three to eight times that of untreated fields depending upon the kind of insect control program followed.

Aphids also can cause severe damage on alfalfa growth when their populations are high. Franklin (1953) conducted studies which determined that alfalfa plants in plots treated for pea aphid control increased in height from 19.0-40.0 per cent more than plants in untreated plots, and alfalfa yield was increased 152.0 per cent.

Aphid infestations also can influence alfalfa seed production. Johnson (1960) ascertained that clover aphid damage to red clover reduced the number of seeds produced and the weight of individual seeds from 6.6-8.8 per cent. Sixty per cent of this loss was because of reduction in weight and 40.0 per cent was attributable to the reduction in the number of seeds.

Commonly in late summer and early fall, grasshoppers are quite numerous in forage crop fields and sometimes they feed rather heavily on alfalfa and other legumes. The alfalfa weevil causes most of its damage also by chewing, but this occurs mainly from early spring to summer.

The combined effects of the feeding habits of this complex of chewing and sucking insects often reduce the quality and quantity of harvest- 
able alfalfa. This fact merits serious consideration for the control of these pests by producers of alfalfa.

As the result of several years of observations and survey activities, it has been determined that some of the most prevalent insect pests of alfalfa in West Virginia are: LEAFHOPPERS-the potato leafhopper, Empoasca fabae (Harris); the clover leafhopper, Aceratagallia sanguinolenta (Provancher) and Agallia constricta Van Duzee. APHIDS-the pea aphid, Macrosiphum pisi (Kaltenbach); the clover aphid, Anuraphis bakeri (Cowen); and the potentially very destructive spotted alfalfa aphid, Therioaphis maculata (Buckton) is present in the State. SPITTLEBUGS-the meadow spittlebug, Spumarius lencophthalmus (Linnaeus); PLANT BUGS-the tarnished plant bug, Lygus lineolaris (Beauvois); the alfalfa plant bug, Adelphocoris lineolatus (Goeze) and Reuteroscopus ornatus (Reuter). GRASSHOPPERS-the Carolina grasshopper, Dissosteira carolina (Linnaeus); the red-legged grasshopper, Melanoplus femurrubrum (DeGeer); the two-striped grasshopper, M. bivittatus (Say); and the differential grasshopper, M. differentialis (Thomas). IVEEVILS-the alfalfa weevil, Hypera postica (Gyllenhal); the clover leaf weevil, H. punctata (Fabricius); the clover weevils, Sitona spp. BLISTER BEETLES-the black blister beetle, Epicauta pennsylvanica (DeGeer); and the ash-gray blister beetle, E. fabricii (LeConte).

Table 1 lists the most prevalent economic species of insect pests of alfalfa in West Virginia according to their comparative prevalence at the time of this study.

Location of Experimental Plots-In 1959 experimental alfalfa insect control plots were established for the purpose of determining effective control methods against these pests. The plots were located on several farms in the eastern panhandle area of the State; they were all replicated twice and varied in size from $1 / 32$ to $\frac{1}{2} \mathrm{~A}$. The plots were arranged so that there was a six-foot buffer (untreated) strip between treatments.

Method of Applying the Insecticides-The spray formulations were applied with high pressure (125-250 p.s.i.), high volume (25-40 gal./A.), hydraulic sprayers equipped with a 20 -ft. boom. Granular formulations were applied with cyclone-type seeders, either hand-operated or batterypowered, tractor-mounted types.

Method of Sampling Insect Populations-The plots were sampled for insect control evaluation purposes by sweeping them with a 15 -inch diameter beating net ( 25 sweeps per treatment replicate, per sampling date). The samples were taken from the longitudinal median of each plot.

Insecticides Applied on the Experimental Plots-Various spray and granular formulations of 42 insecticides were applied on the plots for al- 


\section{Common Pests of Alfalfa in West Virginia and Their Prevalence}

PLANT BUGS-Hemiptera, Miridae

Lygus lineolaris (Beauvois)

Adelphocoris lineolatus (Goeze)

Reuteroscopus ornatus Reuter

Ilnacora stalii Reuter

Plagiognathus politus Uhler

Rank

LEAFHOPPERS-Homoptera, Cicadellidae

Aceratagallia sanguinolenta (Provancher)

Agallia constricta Van D.

Empoasca fabae (Harris)

Draeculacephela antica (Walker)

Graminella nigrofrons (Forbes)

Deltocephalus flavocostatus Van Duzee

SPITTLEBUGS-Homoptera, Cercopidae

Spumarius leucophthalmus (Linneaus)

APHIDS-Homoptera, Aphidae Macrosiphutm pisi (KaItenbach) Anuraphis bakeri (Cowen)

GRASSHOPPERS-Orthoptera, Acrididae

Dissosteira carolina (Linnaeus)

Melanoplus femurrubrum (DeGeer)

$M$. differentialis (Thomas)

M. bivittatus (Say)

WEEVILS-Coleoptera, Curculionidae

Hypera postica (Gyllenhal)

H. punctata (Fabricius)

Sitona spp.

Epicauta pennsylvanica (DeGeer) Epicauta fabricii (LeConte)

\section{BLISTER BEETLES-Coleoptera, Meloidae}

falfa insect control evaluations. The insecticides included in these studies were: diazinon (S. \& G. $)^{1}$; phosphamidon (S.); carbaryl (S.); Alfatox® (diazinon + methoxychlor) (S.); malathion (S.); heptachlor (S. \& G.); lindane (S.); phorate (G.); dimethoate (S. \& G.); Guthion® (azinphosmethyl) (S.); methyl ethyl azinphosmethyl (S. \& G.); dimetilan (S.); Ciodrin ${ }^{\circledR}$ (S.), alpha-methylbenzyl 3-hydroxycrotonate dimethyl phosphate; Telodrin ${ }^{\circledR}$ (S. \& G.), 1,3,4,5,6,7,8,8-octachloro-1,3,3a4,7,7a-hexahydro-4,7-methanoisbenzofuran; SD-8447 (S. \& G.), 2-chloro-1-(2,4,5-tri- 
chlorophenyl) vinyl dimethyl phosphate; SD-8448 (S.), (2-chloro-1(2,4,5-trichlorophenyl) vinyl dimethyl phosphate); SD-9129 (S.), dimethyl phosphate ester with 3-hydroxy-N-methyl-ciscrotanamide; SD7438 (S. \& G.), (Toluene-alpha, alpha-dithiol bis (0,0-dimethyl phosphorodithioate); American Cyanamid 47470 (S.), cyclic propylene (dithoxyphosphinyl) dithioimidocarbonate; American Cyanamid 43064 (S.), 2-(diethoxyphosphinothiolimino)-1,3-dithiolane; A m e r i c a n Cyanamid 47031 (S.), (2-diethoxyphosphinylimino)-1,3-dithiolane, American Cyanamid 47472 (S.), 2-(dimethoxyphosphinylimino)-4-methyl-1-3 dithiolane; General Chemical 4072 (S. \& G.), 2-chloro-1-(2,4-dichlorophenyl) vinyl diethyl phosphate; Zinophos ${ }^{\circledR}$ (cynem) (S. \& G.), 0,0-diethyl 0-2 pyrazinyl phosphorothioate; Bayer 25141 (G.), 0,0-diethyl 0-p-(methylsulfinyl)-phenyl phosphorothioate; Monsanto CP-40294 (S. \& G.), 0-pn itrophenyl methylphosphorothioate; Thiodan (endosulfan) (S.) (6,7,8,9,10,10-hexachloro-1,5,5a,6,9,9a-hexahydro-6,9-methano-2,4,3-benzodioxathiepin-3-oxide); American Cyanamid 52160 (S.), 0,0,0'-tetramethyl $0,0^{\prime}$-thiodi-p-phenylene phosphorothioate; GS-13005 (S.), 0,0,dimethylphos-phorodithioate S-ester with 4 (mercaptomethyl 1)-2-methoxy- $\Delta 2$ 1,3,4-thiodiazolin-5-one; Imidan ${ }^{\circledR}$ (S. \& G.), (0,0-dimethyl S-phthalimidomethyl phosphorodithioate); Dylox® (trichlorfon) (S.), (0,0,dimethyl 2,2,2-trichloro-1-hydroxy-ethyl phosphonate); Zectran ${ }^{\circledR}$ (S.), 4-dimethyllamine-3,5-xylyl methylcarbamate; Tiguvon ${ }^{\circledR}$ (fenthion) (S.), 0,0-dimethyl 0-[4-(methylthio )-m-tolyl] phosphorothioate.

The results of insect control after the application of these various treatments are presented in Tables 2-6.

\section{RESULTS OF INSECTICIDAL TREATMENTS}

Leafhopper Control-1959 (Table 2). In Site 1, the plots treated with malathion $(1.25)^{2}$ and diazinon (0.5) sprays provided the best control for one week of the four insecticides tested. The best two-week posttreatment control resulted from the use of malathion (1.25) spray though this was also not economically effective.

Malathion (1.25) and Thiodan (0.5) sprays gave the best control for one week, but the control was not adequate in Site 2; all treatments were ineffective two weeks after treatment.

1960 (Table 2B). Leafhopper control in Site 3 was evaluated four weeks after treatment. The best reduction came from the use of spray applications of Thiodan ${ }^{\circledR}(0.5)$, diazinon $(0.5)$, and dimethoate $(0.5)$, though this was not adequate control. There were no significant differences between the five insecticides five weeks post-treatment, though

2Amount of actual insecticide applied in pounds per acre 
dimethoate (0.5) spray was slightly more effective than the other treatments.

\section{TABLE 2}

\section{Experimental Control of Leafhoppers (1959-1964)}

\section{Site 1 (Plots $\left(\frac{1}{2} \mathrm{~A} \times 2\right)$}

(Coll. 7-2-59, Av. No. Untrt'd. 152/25 Sweeps)

\begin{tabular}{|c|c|c|c|c|}
\hline Treatments ${ }^{\mathrm{a}}$ & 1S & $2 S$ & $3 S$ & $4 \mathrm{G}$ \\
\hline Per Cent Population Reduction ${ }^{\mathrm{b}}$ & 11.0 & 9.0 & 0.0 & 0.0 \\
\hline
\end{tabular}

(Coll. 7-9-59, Av. No. Untrt'd. 38)

Treatments

Per Cent Population Reduction

\begin{tabular}{cccc}
$2 \mathrm{~S}$ & $1 \mathrm{~S}$ & $4 \mathrm{G}$ & $3 \mathrm{~S}$ \\
\hline 100.0 & 31.0 & 6.0 & 0.0 \\
& & & \\
& & &
\end{tabular}

${ }^{\text {a}}$ Treatments: (All spraying hydraulic, $100 \mathrm{psi}, 50 \mathrm{G} / \mathrm{A}$; treated 6-26-59)

1. Diazinon, Spray (S), (O.5 lb/A)

2. Malathion (S), (1.25)

3. Thiodan (S), (0.5)

4. Heptachlor, Granular (G), (1.0)

'Duncan's Multiple Range Test (5.0 per cent level) for Log $(\mathrm{N}+1)$ of the data; treatments sharing a line in common do not differ in effectiveness.

\section{TABLE 2A}

\section{Experimental Control of Leafhoppers (1959-1964)}

Site 2 (Plots $1 / 4 \mathrm{~A} \times 2$ )

(Coll. 7-17-59, Av. No. Untrt'd. 80/25 Sweeps)

Treatments ${ }^{\mathrm{a}}$

Per Cent Population Reduction ${ }^{\mathrm{b}}$

\begin{tabular}{cccc}
$2 \mathrm{~S}$ & $3 \mathrm{~S}$ & $1 \mathrm{~S}$ & $4 \mathrm{G}$ \\
\hline 50.0 & 32.0 & 0.0 & 0.0
\end{tabular}

(Coll. 7-24-59, Av. No. Untrt'd. 82)

Treatments

Per Cent Population Reduction

\begin{tabular}{cccr}
$3 \mathrm{~S}$ & $2 \mathrm{~S}$ & $4 \mathrm{G}$ & $1 \mathrm{~S}$ \\
\hline 28.0 & 14.0 & 8.0 & 0.0
\end{tabular}

${ }^{2}$ Treatments: (All spraying hydraulic, $100 \mathrm{psi}, 50 \mathrm{G} / \mathrm{A}$; treated 7-10-59)

1. Diazinon (0.5)

2. Malathion (1.25)

3. Thiodan $(0.5)$

4. Heptachlor (1.0)

bDuncan's Multiple Range Test (5.0 per cent level) for $\log (\mathrm{N}+\mathrm{I})$ of the data; treatments sharing a line in common do not differ in effectiveness. 
Experimental Control of Leafhoppers (1959-1964)

Site 3 (Plots $1 / 8 \mathrm{~A} \times 2$ )

(Coll. 5-20-60, Av. No. Untrt'd. 9/25 Sweeps)

\begin{tabular}{cccccc} 
Treatments $^{\mathrm{a}}$ & $1 \mathrm{~S}$ & $2 \mathrm{~S}$ & $3 \mathrm{~S}$ & $4 \mathrm{G}$ & $5 \mathrm{~S}$ \\
\cline { 2 - 6 } Per Cent Population Reduction & \\
& 21.0 & 18.0 & 13.0 & 0.0 & 0.0 \\
\cline { 2 - 5 }
\end{tabular}

(Coll. 5-27-60, Av. No. Untrt'd. 34)

\begin{tabular}{cccccc} 
Treatments $^{\mathrm{a}}$ & $3 \mathrm{~S}$ & $4 \mathrm{G}$ & $2 \mathrm{~S}$ & $5 \mathrm{~S}$ & $1 \mathrm{~S}$ \\
\cline { 2 - 6 } Per Cent Population Reduction & 39.0 & 31.0 & 23.0 & 22.0 & 22.0 \\
\hline
\end{tabular}

aTreatments: (All spraying hydraulic, 125 psi, 44 G/A; treated 4-23-60)

1. Thiodan $(0.5)$

2. Diazinon (0.5)

3. Dimethoate (0.5)

4. Phorate (1.0)

5. Malathion (1.25)

${ }^{\text {b}}$ Duncan's Multiple Range Test $(5.0$ per cent level) for $\log (\mathrm{N}+1)$ of the data; treatments sharing a line in common do not differ in effectiveness.

1961 ( Table 2C). Cynem (1.5), malathion (1.0), and Zectran sprays gave the best leafhopper control one week post-treatment in the plots in Site 4, but control was ineffective. Two weeks after treatment none of the treatments gave satisfactory control.

1962 (Table 2D). Plots in Site 5 were treated with eight different insecticides and of these cynem (1.0) granules provided the best control for three weeks, but it was not significantly different from control resulting from the use of heptachlor (0.12), azinphosmethyl (0.75) sprays, or Telodrin (1.0) granules. None gave satisfactory economic control this late after treatment and none was effective four weeks after treatment.

Excellent to good control for two weeks was obtained in Site 6 (Table 2E) with diazinon (0.75), azinphosmethyl (0.5), dimethoate (0.5), lindane (0.5), Ciodrin (1.0), malathion (1.0) and cynem (1.0) sprays. All treatments were ineffective three weeks after treatment.

Good leafhopper control was evident for one week in Site 7 (Table $2 \mathrm{~F}$ ) in plots treated with diazinon (0.75), Imidan (0.5), and Ciodrin (0.8) sprays. Fair to good control two weeks after treatment persisted with treatments of Ciodrin (0.8), cynem 1.0, and American Cyanamid 43064 ( 0.5 ) sprays, and in the three weeks post-treatment period cynem (1.0), Telodrin (0.25), and azinphosmethyl (0.5) sprays provided fair to good control, though these treatments were not significantly different from six other spray treatments. 
TABLE 2C

Experimental Control of Leafhoppers (1959-1964)

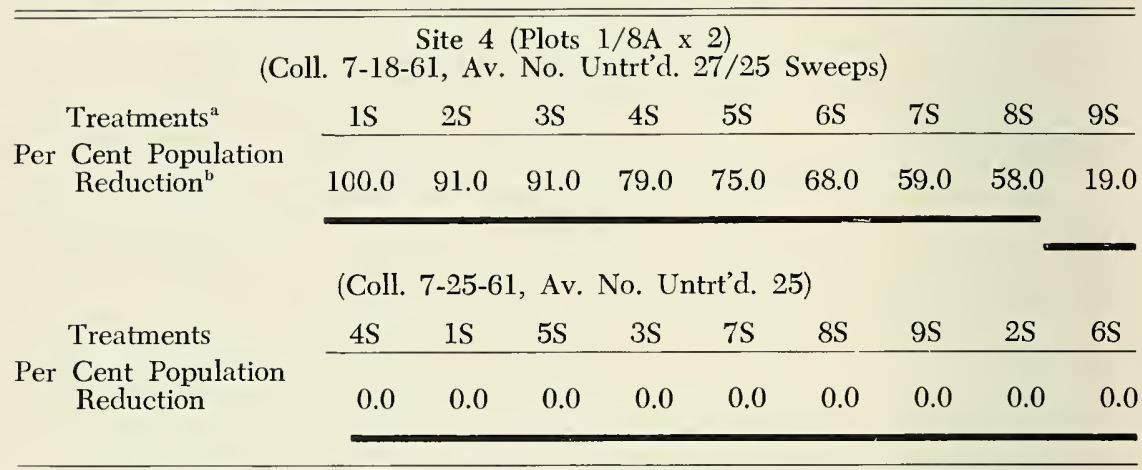

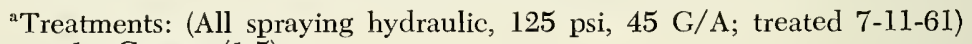

1. Cynem (1.5)

2. Malathion (1.0)

3. Zectran $(0.75)$

4. Diazinon (0.75)

5. Cynem (3.0)

6. Phosphamidon $(0.25)$

7. Trichlorofon $(1.0)$

8. Fenthion (1.0)

9. Carbaryl (1.0)

${ }^{b}$ Duncan's Multiple Range Test (5.0 per cent level) for Log $(N+1)$ of the data; treatments sharing a line in common do not differ in effectiveness.

1963 (Table 2G). Spring treatments of the plots in Site 8 with dimethoate (1.0) and azinphosmethyl (0.75) sprays gave excellent to good control for two weeks. None of the five treatments provided economic control for three weeks.

In Site 9 (Table $2 \mathrm{H}$ ) malathion (2.0) spray gave excellent control for three weeks; azinphosmethyl (0.75) spray was the next most effective treatment in this test.

Eleven spray treatments were applied on the plots in Site 10 (Table 2I). Leafhopper control was good to fair for one week after using the following applications: SD-4072 (1.0), SD-8447 (0.5), malathion (1.0), methyl ethyl azinphosmethyl (0.5), diazinon (0.75), SD-8447 (1.0), American Cyanamid 47470 (0.75), and dimethoate (0.5). Malathion (1.0) spray provided good control three weeks post-treatment.

The plots in Site 11 (Table 2J) were treated in the fall (10-14-63) and were sampled the following spring (5-6 and 5-14-64). On May 6, methyl ethyl azinphosmethyl (1.0) granules showed excellent leafhopper control results. One week later (May 14) only phorate (1.0) granules gave fair to good control of leafhoppers. 


\section{Experimental Control of Leafhoppers (1959-1964)}

Site 5 (Plots $1 / 16 \mathrm{~A} \times 2$ )

(Coll. 5-9-62, Av. No. Untrt'd. 12/25 Sweeps)

\begin{tabular}{|c|c|c|c|c|c|c|c|c|}
\hline \multirow{2}{*}{$\begin{array}{l}\text { Treatments } \\
\text { Per } \begin{array}{l}\text { Cent Population } \\
\text { Reduction }\end{array}\end{array}$} & $1 \mathrm{G}$ & $2 S$ & $3 \mathrm{~S}$ & $4 \mathrm{G}$ & $5 \mathrm{G}$ & $6 \mathrm{~S}$ & $7 \mathrm{~S}$ & $8 \mathrm{G}$ \\
\hline & 41.0 & 35.0 & 19.0 & 10.0 & 0.0 & 0.0 & 0.0 & \\
\hline
\end{tabular}

(Coll. 5-16-62, Av. No. Untrt'd. 51/25 Sweeps)

Treatments ${ }^{\mathrm{a}}$ Per Cent Population Reduction

\begin{tabular}{cccccccc}
$5 \mathrm{G}$ & $1 \mathrm{G}$ & $4 \mathrm{G}$ & $6 \mathrm{~S}$ & $8 \mathrm{G}$ & $2 \mathrm{~S}$ & $3 \mathrm{~S}$ & $7 \mathrm{~S}$ \\
29.0 & 9.0 & 7.0 & 5.0 & 4.0 & 0.0 & 0.0 & 0.0 \\
\hline
\end{tabular}

"Treatments: (All spraying hydraulic, 250 psi, $27 \mathrm{G} / \mathrm{A}$; treated 4-18-62)

1. Cynem (1.0)

2. Heptachlor $(0.12)$

3. Azinphosmethyl (0.75)

4. Telodrin, G. (0.5)

5. American Cyanamid \#43064 (1.0)

6. Telodrin, S. $(0.12)$

7. Ciodrin (1.0)

8. Imidan (1.0)

'Duncan's Multiple Range Test (5.0 per cent level) for Log $(\mathrm{N}+1)$ of the data; treatments sharing a line in common do not differ in effectiveness.

1964 (Table 2K). Twenty-four different insecticides were applied on the plots in Site 12. Two weeks later none of the insecticides gave economic control of leafhoppers and there was no significant difference between treatments. Three weeks after treatment there were significant differences between treatments, but none provided satisfactory economic control (American Cyanamid 52160 (1.0) only gave fair control).

Plant Bug Control-1959 (Table 3). In Site 1, heptachlor (1.0) granules and Thiodan (0.5) spray gave comparable, but not economic control, of plant bugs one and two weeks, post-treatment.

Similar results were observed in the plots of Site 2 (Table $3 \mathrm{~A}$ ) with the same insecticides (slightly better control) one week and two weeks after treatment.

1960 (Table 3B). Malathion (1.25) spray produced excellent plant bug control for as long as four weeks after treatment in Site 3.

Phorate (1.0) granules gave fair economic control for as long as four weeks Site 4 (Table 3C).

1961 (Table 3D). All of the eight spray treatments in Site 5 provided excellent control except carbaryl (1.0) one week after treatment. 


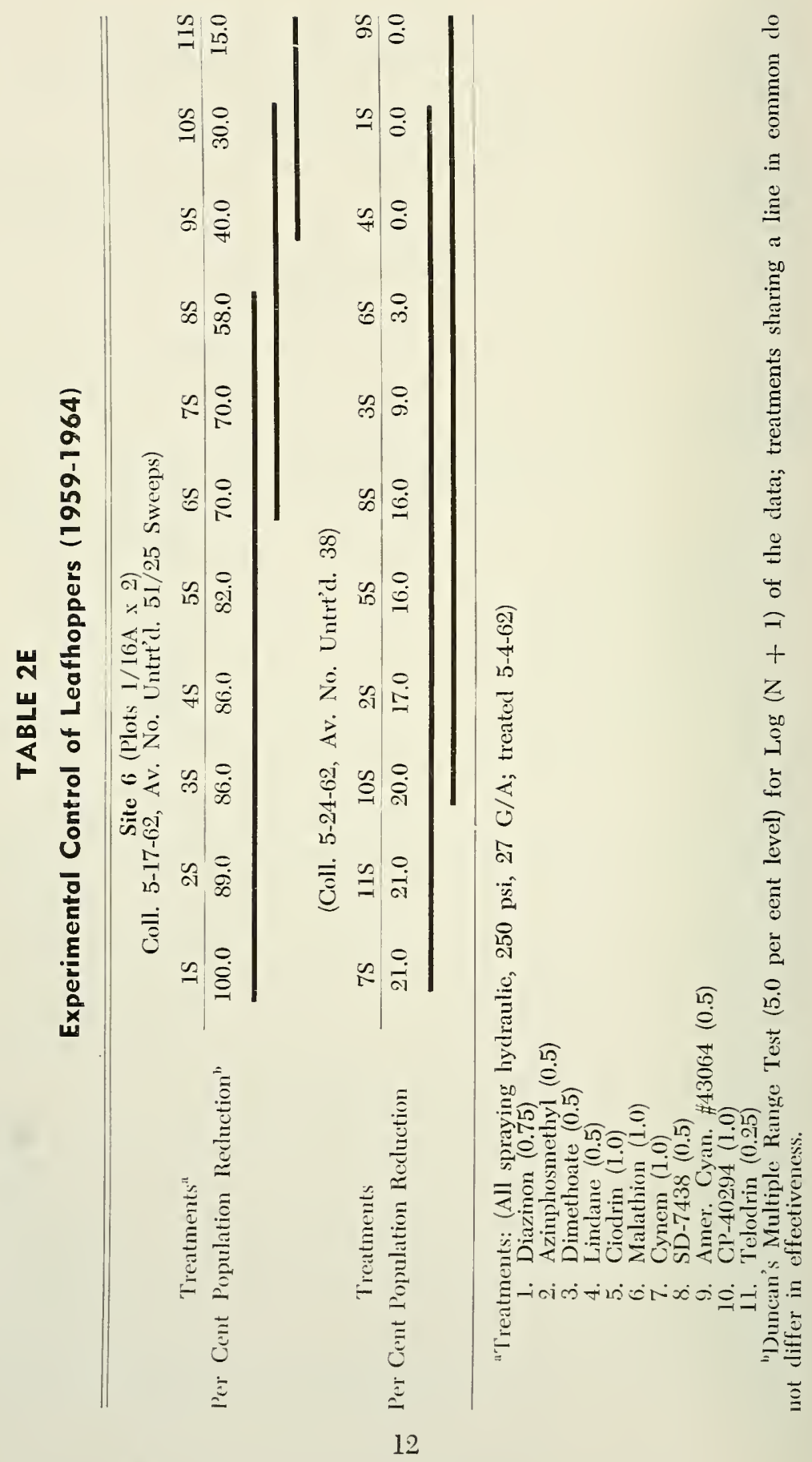




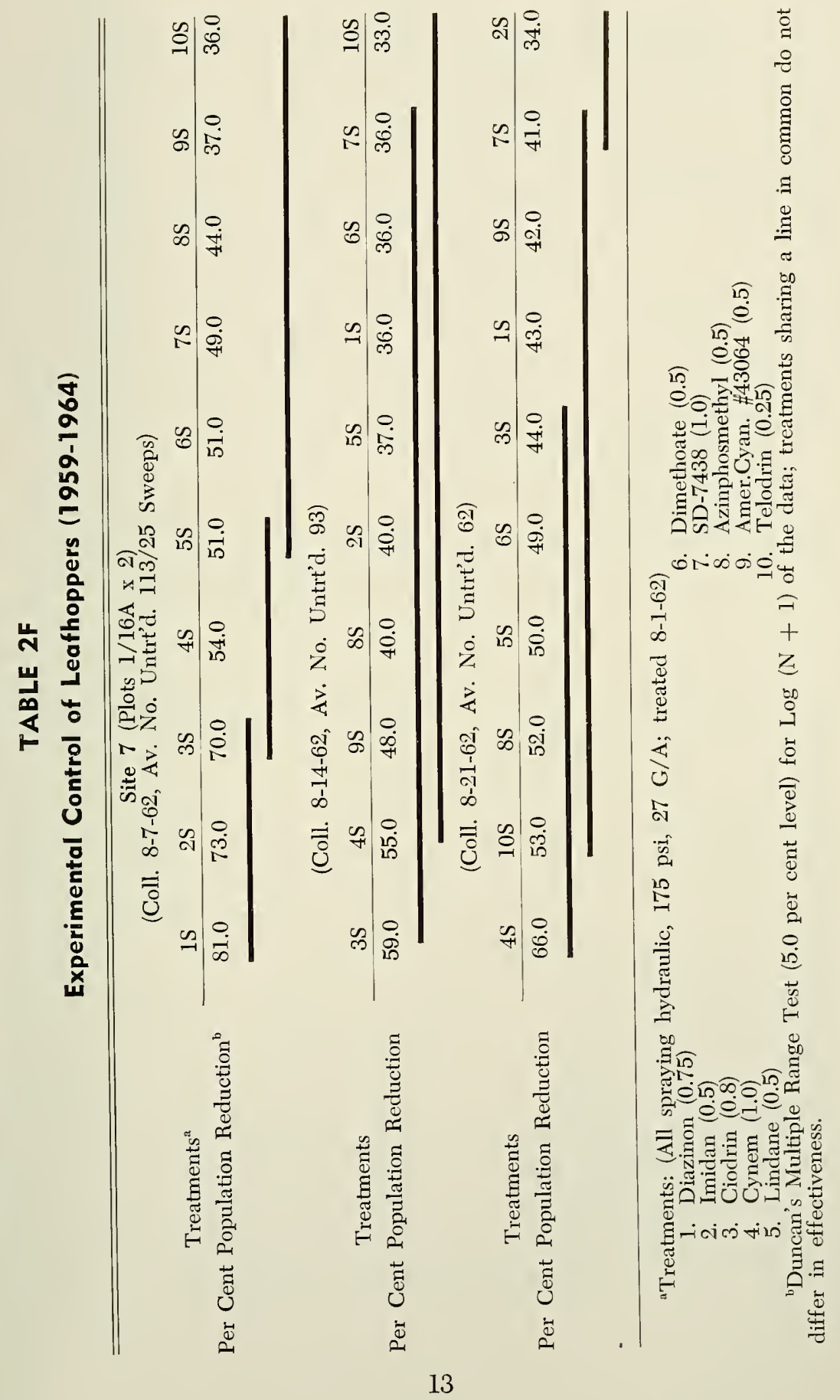




\section{Experimental Control of Leafhoppers (1959-1964)}

Site 8 (Plots $1 / 2 \mathrm{~A} \times 2$ )

(Coll. 5-9-63, Av. No. Untrt'd. 10/25 Sweeps)

Treatments $^{\mathrm{a}}$

Per Cent Population Reduction ${ }^{\mathrm{b}}$

\begin{tabular}{ccccc}
$1 \mathrm{~S}$ & $2 \mathrm{~S}$ & $3 \mathrm{~S}$ & $4 \mathrm{~S}$ & $5 \mathrm{~S}$ \\
\hline 100.0 & 52.0 & 6.0 & 5.0 & 0.0 \\
\hline
\end{tabular}

(Coll. 5-16-63, Av. No. Untrt'd. 10)

Treatments

Per Cent Population Reduction

\begin{tabular}{ccccc}
$2 \mathrm{~S}$ & $5 \mathrm{~S}$ & $1 \mathrm{~S}$ & $3 \mathrm{~S}$ & $4 \mathrm{~S}$ \\
\hline 47.0 & 43.0 & 21.0 & 20.0 & 20.0
\end{tabular}

${ }^{a}$ Treatments: (All spraying hydraulic, $125 \mathrm{psi}, 40 \mathrm{G} / \mathrm{A}$; treated 4-24-63)

1. Dimethoate (1.0)

2. Azinphosmethyl (0.75)

3. Diazinon (0.75)

4. Carbaryl (1.0)

5. Malathion (1.0)

${ }^{b}$ Duncan's Multiple Range Test (5.0 per cent level) for $\log (\mathrm{N}+1)$ of the data; treatments sharing a line in common do not differ in effectiveness.

TABLE 2H

Experimental Control of Leafhoppers (1959-1964)

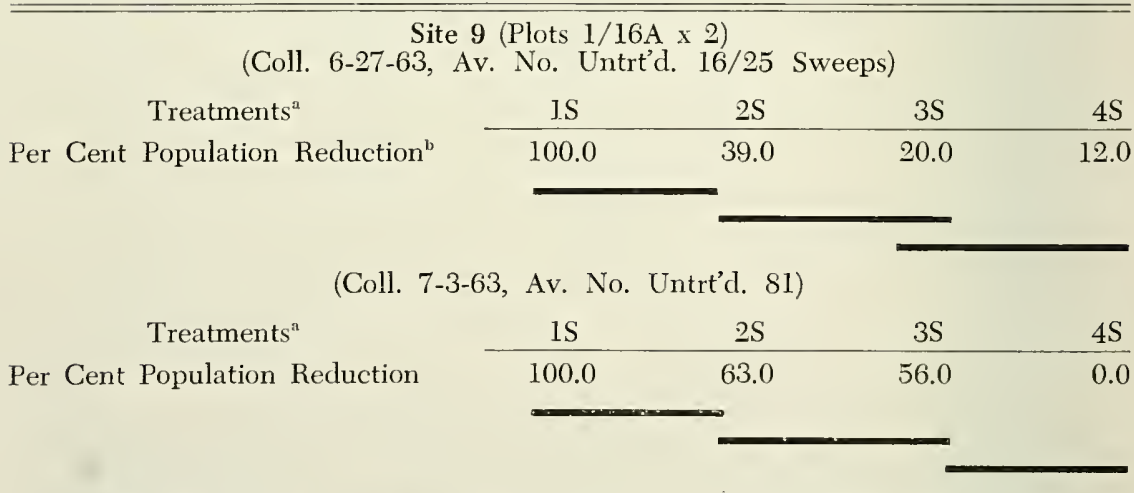

aTreatments: (All spraying hydraulic, 175 psi, 27 G/A; treated 6-15-63)

1. Malathion (2.0)

2. Azinphosmethyl (0.75)

3. Dimethoate $(0.5)$

4. Malathion (1.0)

'Duncan's Multiple Range Test (5.0 per cent level) for $\log (\mathrm{N}+1)$ of the data; treatments sharing a line in common do not differ in effectiveness. 


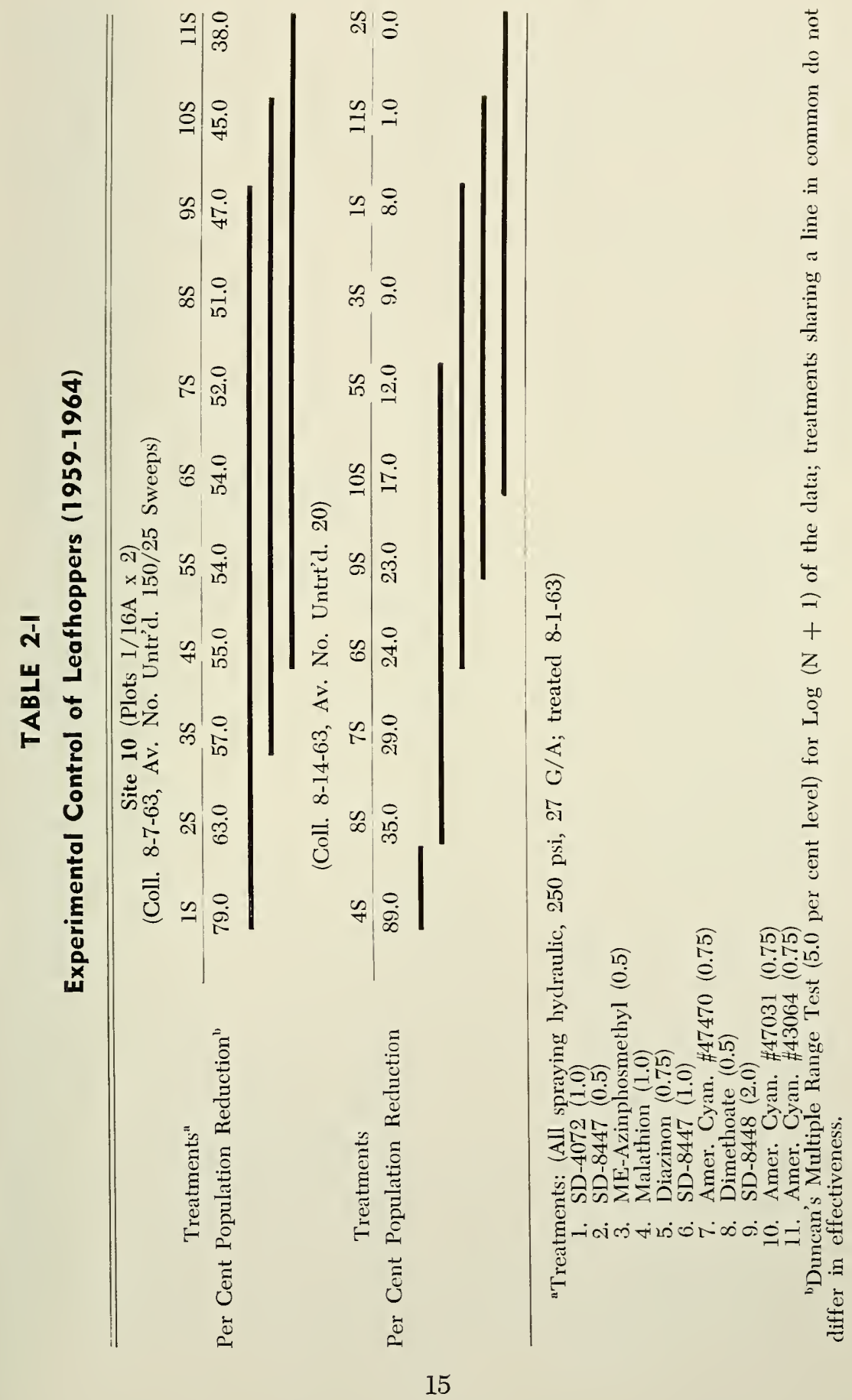




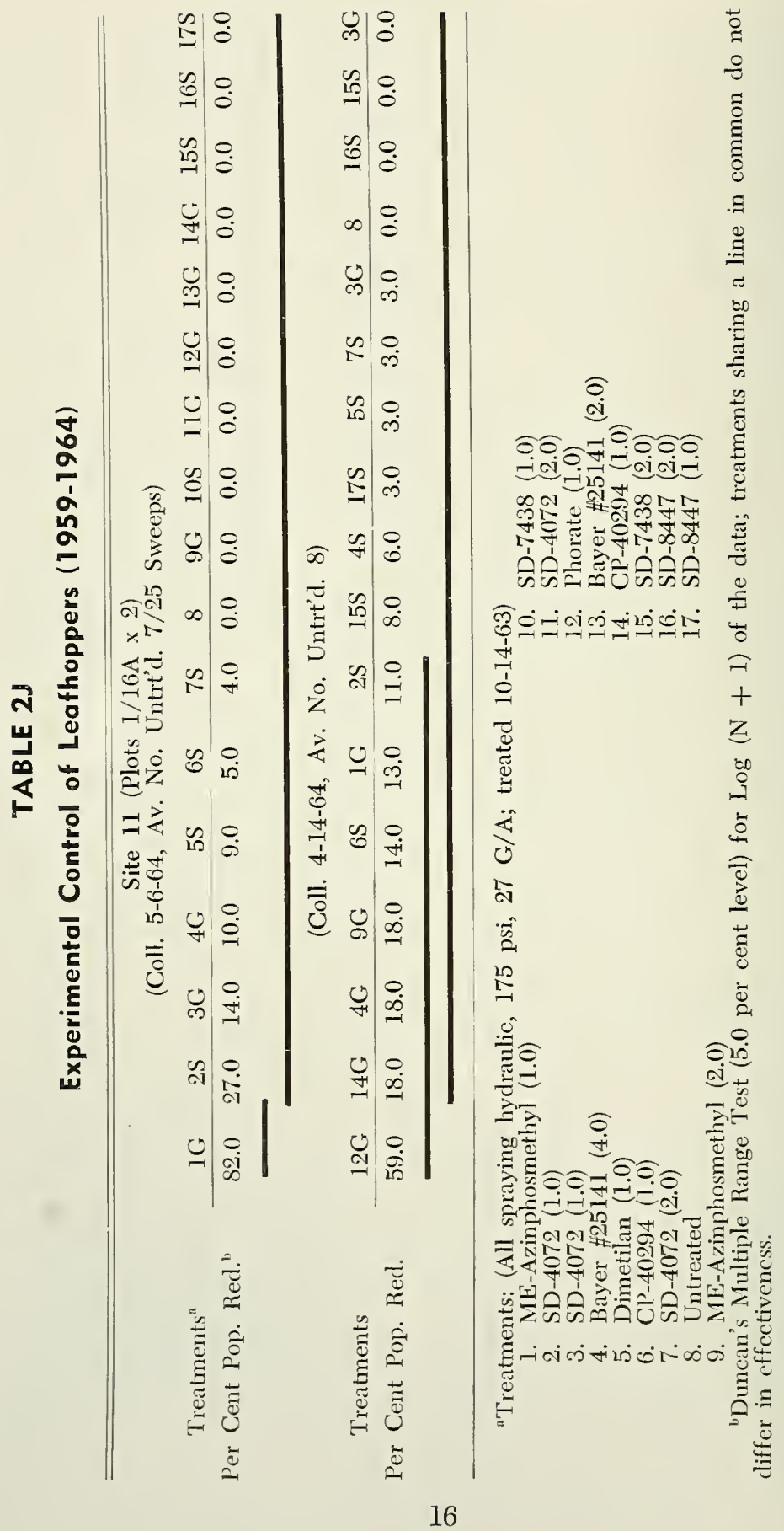


Two weeks after treatment none of the insecticides gave satisfactory control.

In Site 6 (Table 3E) Imidan (0.75) spray provided excellent plant bug control during the period of the first sampling date and the granular formulation ( 0.75 ) gave slightly better, but inadequate, control one week later (sampled seven months after fall treatment).

1962 (Table 3F). There were five insecticides applied in Site 7 and, of these, only Telodrin (2.5) granules gave excellent control three weeks post-treatment. In the four weeks post-treatment period Ciodrin (1.0) spray evidenced excellent control of plant bugs.

Ciodrin (0.8) spray also gave the best (good) control results in Site 8 (Table 3G) one week after treatment although the results were not significantly different from dimethoate $(0.5)$, lindane $(0.5)$, malathion (1.0), cynem (1.0), Telodrin (0.25) and American Cyanamid 43064 (0.5) and Imidan (0.5) sprays. None of the insecticides were effective two weeks post-treatment.

1963 (Table 3H). Two weeks after treatment both malathion (1.0) and (2.0) sprays gave excellent plant bug control in Site 9. In the three weeks post-treatment period, only malathion (2.0) spray provided excellent control.

The control results in Site 10 (Table 3I) (treated 10-14-63) showed significant differences in evaluations made 5-6 and 5-8-64 (seven months after treatment). Except for SD-8447 (2.0) and CP-50294 (1.0) sprays and methyl ethyl azinphosmethyl (1.0) granules there was no economic control, and even here the results are confusing. It is believed that this is because of the extremely small number of plant bugs available for sampling at this time of the year in the State. The same comments apply to the results of the sampling one week later.

1964 (Table 3J). Twenty-five different insecticides were applied on the plots in Site 11; samples were taken two and three weeks post-treatment. There were no significant differences between most of the treatments in plant bug control for either period. In the two-week post-treatment period, SD-7438 (1.0) and (0.75) granules gave excellent control, dimethoate (0.75) granules and GS-13005 (0.5) spray gave evidence of economic control. This was true also for malathion (1.0), which produced excellent control results, and American Cyanamid 52160 (2.0) sprays and dimethoate $(0.75)$ granules which gave some population reduction during the three week post-treatment period. The low numbers of plant bugs present on the sampling dates probably influenced the control evaluation results as compared by the Duncan's multiple range test.

Grasshopper Control-1959 (Table 4). In the plots of Site 1, treated with malathion (1.25) and diazinon (0.5) sprays grasshoppers were con- 


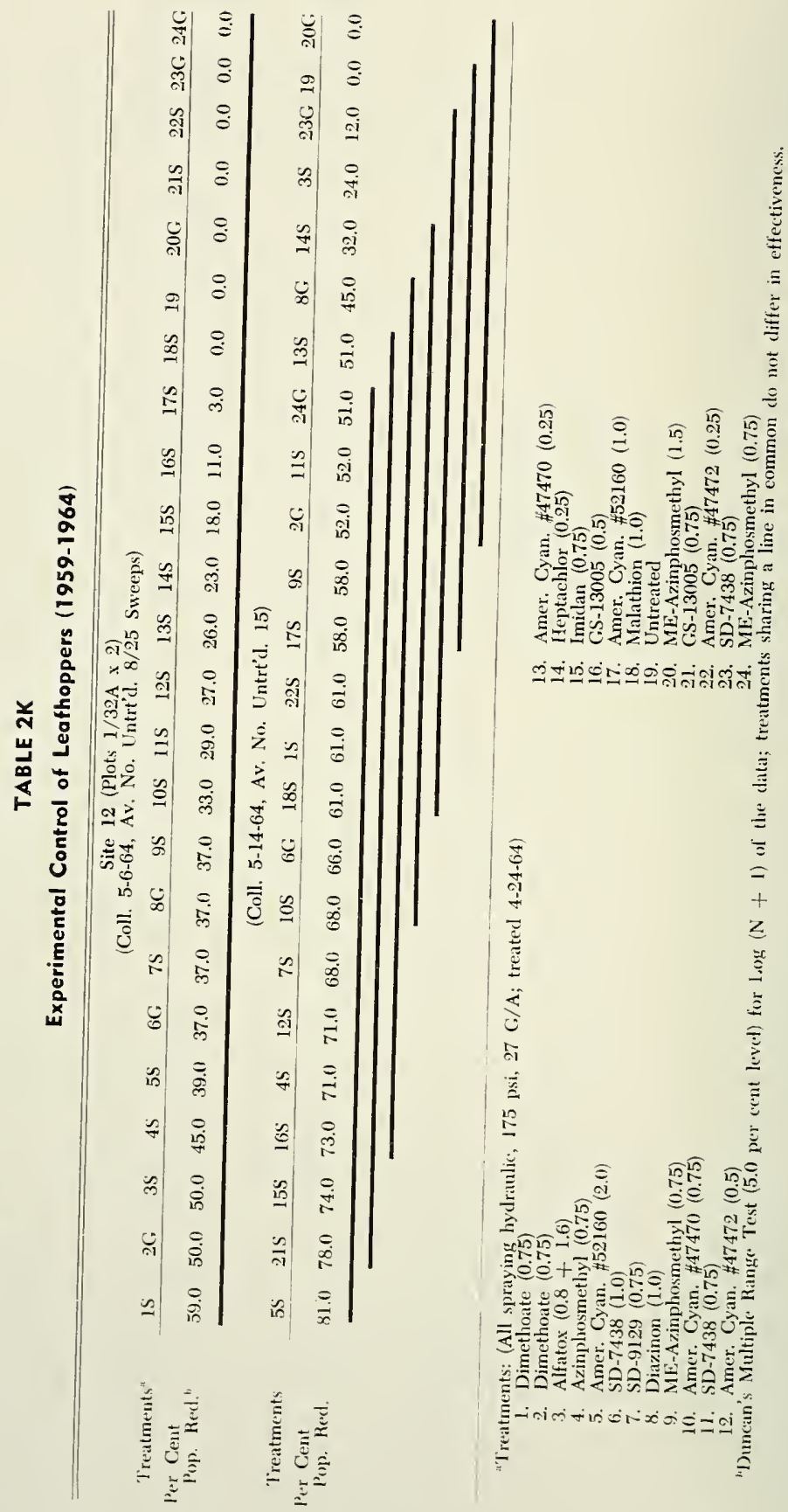


trolled perfectly for one week; malathion gave excellent control for two weeks after treatment.

\section{TABLE 3}

\section{Experimental Control of Plant Bugs (1959-1964)}

Site 1 (Plots $1 / 2 \mathrm{~A} \times 2$ )

(Coll. 7-2-59, Av. No. Untrt'd. 129/25 Sweeps)

\begin{tabular}{|c|c|c|c|c|}
\hline Treatments $^{\mathrm{a}}$ & IG & $2 S$ & $3 S$ & $4 \mathrm{~S}$ \\
\hline Per Cent Population Reduction ${ }^{b}$ & 29.0 & 12.0 & 2.0 & 0.0 \\
\hline
\end{tabular}

(Coll. 7-9-59, Av. No. Untrt'd. 40)

Treatments

Per Cent Population Reduction

\begin{tabular}{cccc}
$2 S$ & $1 G$ & $3 S$ & $4 S$ \\
\hline 18.0 & 17.0 & 11.0 & 3.0 \\
\hline
\end{tabular}

${ }^{a}$ Treatments: (All spraying hydraulic, $100 \mathrm{psi}, 50 \mathrm{G} / \mathrm{A}$; treated 6-26-59)

1. Heptachlor (1.0)

2. Thiodan $(0.5)$

3. Diazinon $(0.5)$

4. Malathion (1.25)

'Duncan's Multiple Range Test (5.0 per cent level) for $\log (\mathrm{N}+1)$ of the data; treatments sharing a line in common do not differ in effectiveness.

TABLE 3A

Experimental Control of Plant Bugs (1959-1964)

Site 2 (Plots $1 / 2 \mathrm{~A} \times 2$ )

(Coll. 7-2-59, Av. No. Untrt'd. 85/25 Sweeps)

Treatments

Per Cent Population Reduction ${ }^{\text {b }}$

\begin{tabular}{cccc}
$1 \mathrm{G}$ & $2 \mathrm{~S}$ & $3 \mathrm{~S}$ & $4 \mathrm{~S}$ \\
\hline 48.0 & 20.0 & 15.0 & 1.0 \\
\hline & & & \\
\hline
\end{tabular}

(Coll. 7-9-59, Av. No. Untrt'd. 43)

Treatments

Per Cent Population Reduction

\begin{tabular}{cccc} 
IG & $2 S$ & $3 S$ & $4 S$ \\
\hline 49.0 & 30.0 & 19.0 & 0.0 \\
\hline & & & \\
\hline
\end{tabular}

aTreatments: (All spraying hydraulic, $100 \mathrm{psi}, 50 \mathrm{G} / \mathrm{A}$; treated 7-10-59)

1. Heptachlor (1.0)

2. Thiodan $(0.5)$

3. Malathion (1.25)

4. Diazinon $(0.5)$

"Duncan's Multiple Range Test (5.0 per cent level) for Log $(\mathrm{N}+1)$ of the data; treatments sharing a line in common do not differ in effectiveness. 
TABLE 3B

Experimental Control of Plant Bugs (1959-1964)

Site 3 (Plots $1 / 8 \mathrm{~A} \times 2$ )

(Coll. 5-15-60, Av. No. Untrt'd. 8/25 Sweeps)

Treatments ${ }^{\mathrm{a}}$

Per Cent Population Reduction ${ }^{\mathrm{b}}$

\begin{tabular}{ll}
$1 \mathrm{~S}$ & $2 \mathrm{~S}$ \\
\hline 85.0 & 0.0 \\
\hline
\end{tabular}

(Coll. 5-22-60, Av. No. Untrt'd. 4)

Treatments

Per Cent Population Reduction

\begin{tabular}{cl}
$1 \mathrm{~S}$ & $2 \mathrm{~S}$ \\
\hline 100.0 & 0.0 \\
\hline
\end{tabular}

aTreatments: (All spraying hydraulic, 125 psi, 44 G/A; treated 4-23-60)

1. Malathion (1.25)

2. Diazinon $(0.5)$

'Duncan's Multiple Range Test (5.0 per cent level) for Log $(\mathrm{N}+1)$ of the data; treatments sharing a line in common do not differ in effectiveness.

TABLE 3C

Experimental Control of Plant Bugs (1959-1964)

Site 4 (Plots $1 / 8 \mathrm{~A} \times 2$ )

(Coll. 5-20-60, Av. No. Untrt'd. 8/25 Sweeps)

Treatments ${ }^{\mathrm{a}}$

Per Cent Population Reduction ${ }^{\mathrm{b}}$

\begin{tabular}{ll}
$1 G$ & $2 S$ \\
\hline 51.0 & 0.0 \\
\hline
\end{tabular}

(Coll. 5-27-60, Av. No. Untrt'd. 4)

Treatments

Per Cent Population Reduction

\begin{tabular}{cc}
$2 \mathrm{~S}$ & $1 \mathrm{G}$ \\
\hline 0.0 & 0.0
\end{tabular}

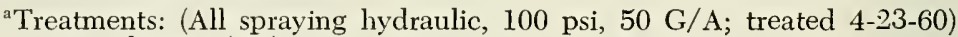

1. Phorate (1.0)

2. Thiodan $(0.5)$

'Duncan's Multiple Range Test (5.0 per cent level) for Log $(\mathrm{N}+1)$ of the data; treatments sharing a line in common do not differ in effectiveness.

Heptachlor (1.0) granules provided excellent control for two weeks; Thiodan (0.5) spray gave excellent control for one week and good control for two weeks in the plots of Site 2 (Table 4A).

1961 (Table 4B). All of the treatments in Site 3 evidenced good to excellent control of grasshoppers. Malathion (1.0), diazinon (0.75), phosphamidom (0.25), Zectran (0.75), and cynem ( 1.5 and 3.0 ) sprays gave perfect control for one week, cynem (1.50 and 3.0) and diazinon (0.75) 


\section{TABLE 3D}

\section{Experimental Control of Plant Bugs (1959-1964)}

Site 5 (Plots $1 / 8 \mathrm{~A} \times 2$ )

(Coll. 7-18-61, Av. No. Untrt'd. 2/25 Sweeps)

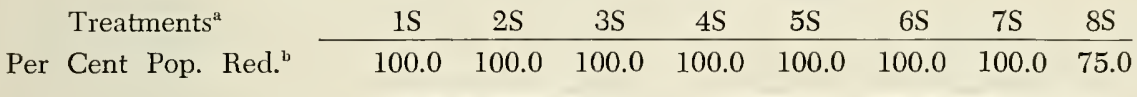

(Coll. 7-25-61, Av. No. Untrt'd. 14)

\begin{tabular}{lcccccccc} 
Treatments & $8 \mathrm{~S}$ & $3 \mathrm{~S}$ & $2 \mathrm{~S}$ & $1 \mathrm{~S}$ & $4 \mathrm{~S}$ & $5 \mathrm{~S}$ & $6 \mathrm{~S}$ & $7 \mathrm{~S}$ \\
\cline { 2 - 10 } Per Cent Pop. Red. & 20.0 & 9.0 & 8.0 & 7.0 & 3.0 & 3.0 & 3.0 & 0.0
\end{tabular}

a'Treatments: (All spraying hydraulic, 125 psi, 45 G/A; treated 7-11-61)
1. Malathion (1.0)
2. Trichlorfon (1.0)
3. Fenthion (1.0)
4. Phosphamidon (0.25)
5. Zectran $(0.75)$
6. Cynem (1.50)
7. Cynem (3.00)
8. Carbaryl (1.0)

'Duncan's Multiple Range Test (5.0 per cent level) for Log $(N+1)$ of the data; treatments sharing a line in common do not differ in effectiveness.

\section{TABLE $3 E$}

\section{Experimental Control of Plant Bugs (1959-1964)}

Site 6 (Plots $1 / 16 \mathrm{~A} \times 2$ )

(Coll. 5-15-62, Av. No. Untrt'd. 2/25 Sweeps)

Treatments ${ }^{\mathrm{a}}$

Per Cent Population Reduction ${ }^{\mathrm{b}}$

\begin{tabular}{cr}
\hline $\mathrm{S}$ & $2 \mathrm{G}$ \\
\hline 100.0 & 50.0 \\
\hline
\end{tabular}

(Coll. 5-22-62, Av. No. Untrt'd. 3)

Treatments

Per Cent Population Reduction

\begin{tabular}{lr}
$2 \mathrm{G}$ & $1 \mathrm{~S}$ \\
\hline 75.0 & 69.0
\end{tabular}

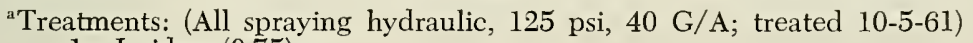

1. Imidan $(0.75)$

2. Imidan $(0.75)$

buncan's Multiple Range Test $(5.0$ per cent level) for Log $(N+1)$ of the data; treatments sharing a line in common do not differ in effectiveness.

sprays good to fair control for two weeks, and cynem (3.0), diazinon $(0.75)$, and trichlorfon (1.0) sprays fair control for three weeks after treatment.

1962 (Table 4C). The plots of Site 4 treated with American Cyanamid 43064 (0.5), azinphosmethyl (0.5), and Ciodrin (0.8) sprays gave 


\section{TABLE 3F}

\section{Experimental Control of Plant Bugs (1959-1964)}

Site 7 (Plots $1 / 16 \mathrm{~A} \times 2$ )

(Coll. 5-9-62, Av. No. Untrt'd. 2/25 Sweeps)

\begin{tabular}{|c|c|c|c|c|c|}
\hline Treatments ${ }^{3}$ & $1 \mathrm{G}$ & $2 S$ & $3 S$ & $4 \mathrm{~S}$ & $5 S$ \\
\hline Per Cent Population Reduction ${ }^{b}$ & 100.0 & 50.0 & 0.0 & 0.0 & 0.0 \\
\hline
\end{tabular}

(Coll. 5-16-62, Av. No. Untrt'd. 2)

Treatments

Per Cent Population Reduction

\begin{tabular}{ccccc}
$2 \mathrm{~S}$ & $1 \mathrm{G}$ & $3 \mathrm{~S}$ & $5 \mathrm{~S}$ & $4 \mathrm{~S}$ \\
\hline 100.0 & 50.0 & 21.0 & 0.0 & 0.0
\end{tabular}

aTreatments: (All spraying hydraulic, $250 \mathrm{psi}, 27 \mathrm{G} / \mathrm{A}$; treated 4-18-62)

1. Telodrin (2.5)

2. Ciodrin (1.0)

3. Imidan (1.0)

4. Telodrin $(0.12)$

5. Cynem (1.0)

${ }^{b}$ Duncan's Multiple Range Test $(5.0$ per cent level) for $\log (\mathrm{N}+1)$ of the data; treatments sharing a line in common do not differ in effectiveness.

good to excellent control for one week. This control was slightly better, but not significantly different from that provided by spray mixtures of dimethoate (0.5), Telodrin (1.0), malathion (1.0), cynem (1.0), and diazinon (0.75). American Cyanamid 43064 (0.5) and malathion (1.0) sprays provided fair control two weeks post-treatment and cynem (1.0) and 43064 gave fair control three weeks post-treatment.

The best grasshopper control was observed in the plots treated with American Cyanamid 47031 (0.75), 43064 (0.75), and 47470 (0.75) sprays in Site 5 (Table 4D) although these results were not significantly better than those in the plots treated with dimethoate (0.5), SD-8448 (2.0), and methyl ethyl azinphosmethyl (0.5) spray one week after treatment. Two weeks after treatment $47470(0.75)$ spray was still giving excellent control, and control with $47031(0.75)$ and dimethoate (0.5) sprays was good.

Aphid Control-1960 (Table 5). Neither malathion (1.0) nor diazinon (0.75) sprays provided satisfactory aphid control in Site 1 for one or two weeks post-treatment. This was also true in Site 2 (Table $5 \mathrm{~A}$ ) for Thiodan (0.5) spray and phorate (1.0) granules.

1961 (Table 5B). In Site 3, Zectran (0.75) spray gave fair control for one week at the 5.0 per cent level test, but none of the treatments were effective two weeks after treatment. Cynem (1.5 and 3.0) sprays demonstrated good population reductions three weeks post-treatment. 


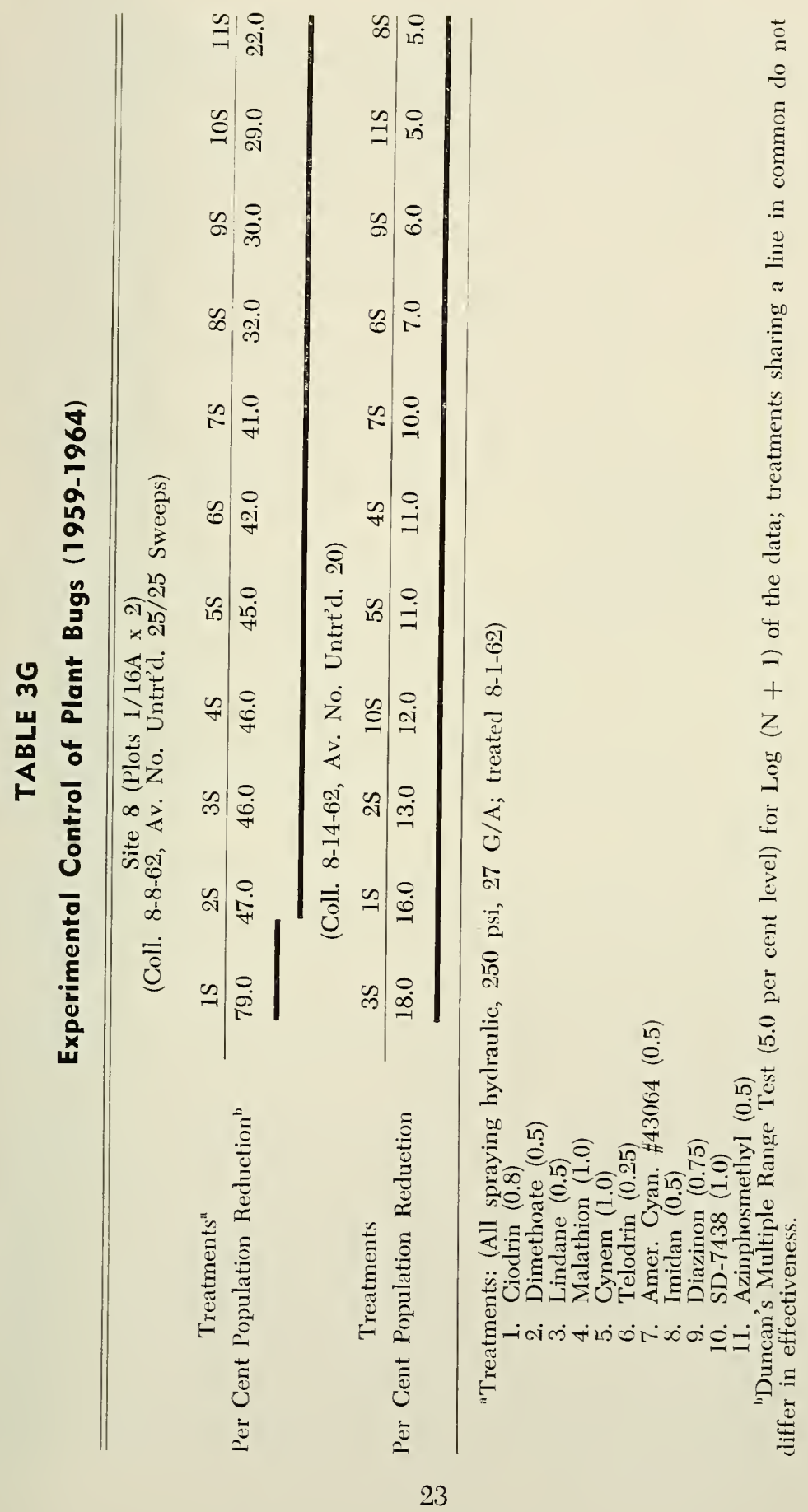




\section{TABLE 3H}

\section{Experimental Control of Plant Bugs (1959-1964)}

Site 9 (Plots $1 / 8 \mathrm{~A} \times 2$ )

(Coll. 6-27-63, Av. No. Untrt'd. 2/25 Sweeps)

Treatments ${ }^{2}$

Per Cent Population Reduction ${ }^{b}$

\begin{tabular}{cccc}
$1 S$ & $2 S$ & $3 S$ & $4 S$ \\
\hline 100.0 & 100.0 & 0.0 & 0.0
\end{tabular}

(Coll. 7-3-63, Av. No. Untrt'd. 6)

Treatments

Per Cent Population Reduction

\begin{tabular}{cccc}
$2 S$ & $4 S$ & $1 S$ & $3 S$ \\
\hline 100.0 & 0.0 & 0.0 & 0.0
\end{tabular}

aTreatments: (All spraying hydraulic, 175 psi, $27 \mathrm{G} / \mathrm{A}$; treated 6-15-63)

1. Malathion (1.0)

2. Malathion (2.0)

3. Dimethoate $(0.5)$

4. Azinphosmethyl (0.75)

'Duncan's Multiple Range Test (5.0 per cent level) for Log $(\mathrm{N}+1)$ of the data; treatments sharing a line in common do not differ in effectiveness.

1962 (Table 5C). Ciodrin (0.8) and Imidan (0.5) sprays gave good aphid control for one week (Site 4); malathion (1.0) spray produced only fair control for two weeks. There were significant differences between the various treatments in the three weeks post-treatment period; lindane (0.5) and dimethoate (0.5) spray treatments were best, but they were not satisfactory.

1963 (Table 5D). There were significant differences between the 10 spray treatments in Site 5 for two weeks. American Cyanamid 47470 $(0.75)$ and dimethoate (0.75) sprays gave excellent control for one week and fair control for two weeks.

None of the 17 insecticides applied in the fall (10-14-63) were effective in controlling aphids the following spring in Site 6 (Table 5E) when sampled 5-6 and 5-14-64.

1964 ( Table 5F). There were significant differences between the 25 insecticides applied in Site 7. None gave satisfactory economic control of aphids two and three weeks after treatment. The best treatments in the two-week period were American Cyanamid 47472 (0.25) and dimethoate (0.75) sprays and diazinon (1.0) granules. The most effective treatments during the three-week post-treatment period were SD-9129 (0.75) and Imidan (.0.75) sprays; the degree of control, however, was not economically significant.

Adult Meadow Spittlebug Control-1959 (Table 6). Thiodan (0.5) spray gave the best one-week and two-week control of adult spittlebugs in Site 1, but control was poor. 


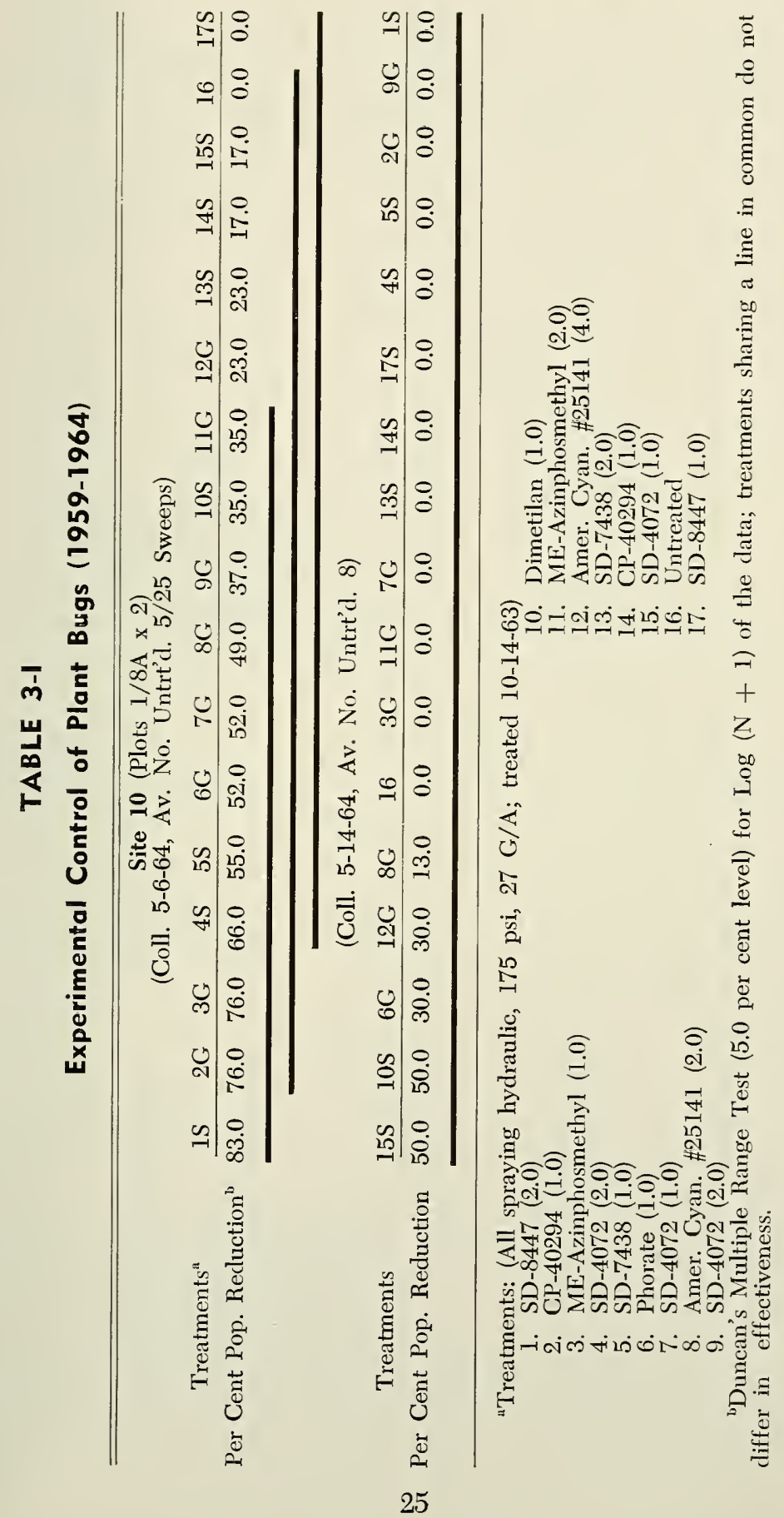




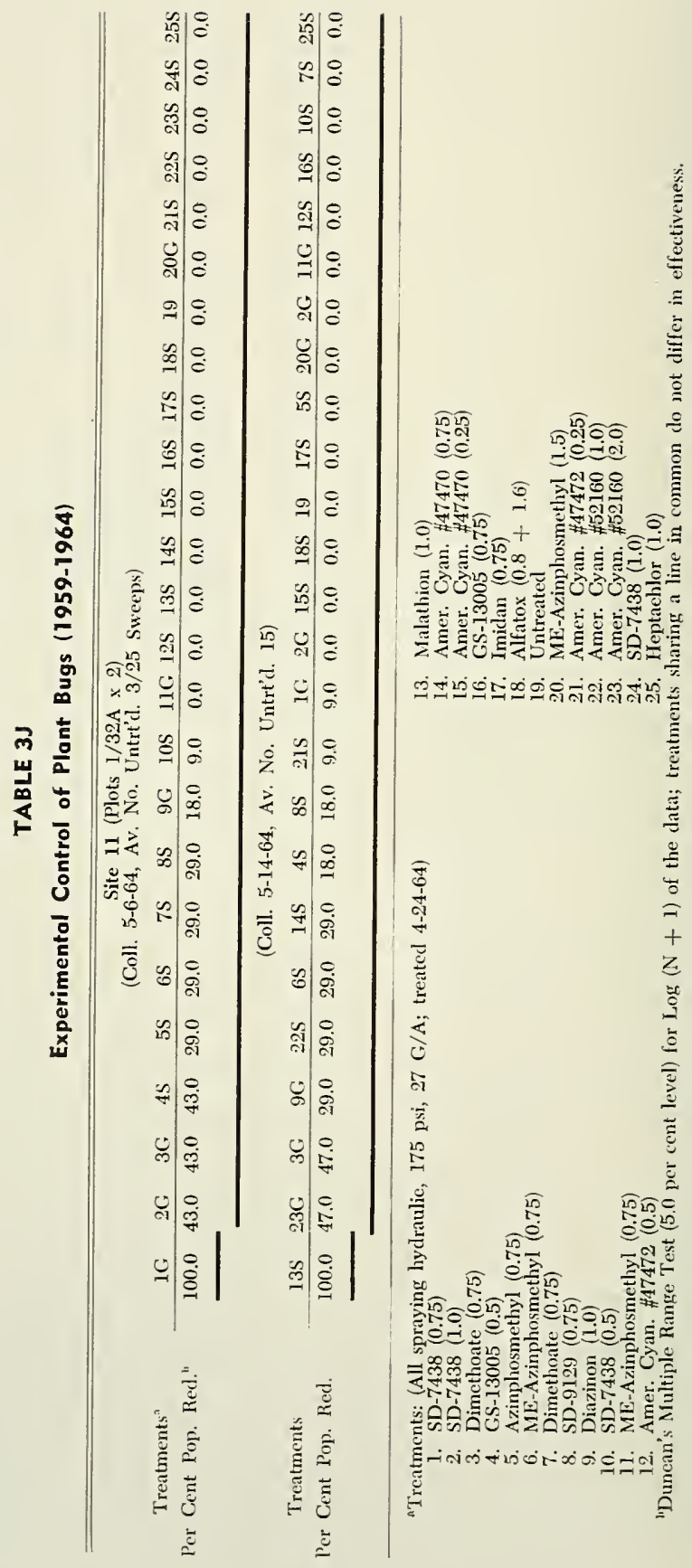


Experimental Control of Grosshoppers (1959-1962)

\begin{tabular}{|c|c|c|c|c|}
\hline \multicolumn{5}{|c|}{$\begin{array}{c}\text { Site } 1 \text { (Plots } 1_{2}^{\prime} \mathrm{A} \times 2 \text { ) } \\
\text { (Coll. 7-2-59, Av. No. Untrt'd. 82/25 Sweeps) }\end{array}$} \\
\hline \multirow[b]{2}{*}{ Per Cent } & Treatments $^{\mathrm{a}}$ & 1S & $2 \mathrm{~S}$ & \multirow{2}{*}{$\begin{array}{l}3 S \\
51.0\end{array}$} \\
\hline & Population Reduction ${ }^{b}$ & 100.0 & 100.0 & \\
\hline \multicolumn{5}{|c|}{ (Coll. 7-9-59, Av. No. Untrt'd. 30) } \\
\hline & Treatments & 1S & $2 S$ & $3 S$ \\
\hline Per Cent & Population Reduction & 100.0 & 46.0 & 21.0 \\
\hline
\end{tabular}

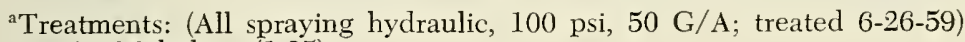

1. Malathion (1.25)

2. Diazinon $(0.5)$

3. Thiodan $(0.5)$

${ }^{b}$ Duncan's Multiple Range Test (5.0 per cent level) for $\log (\mathrm{N}+1)$ of the data; treatments sharing a line in common do not differ in effectiveness.

\section{TABLE 4A}

\section{Experimental Control of Grasshoppers (1959-1962)}

Site 2 (Plots $1 / 2 \mathrm{~A} \times 2$ )

(Coll. 7-17-59, Av. No. Untrt'd. 80/25 Sweeps)

Treatments

Per Cent Population Reduction ${ }^{b}$

\begin{tabular}{cccc}
$1 \mathrm{G}$ & $2 \mathrm{~S}$ & $3 \mathrm{~S}$ & $4 \mathrm{~S}$ \\
\hline 100.0 & 78.0 & 48.0 & 0.0
\end{tabular}

(Coll. 7-24-59, Av. No. Untrt'd. 34)

Treatments

\begin{tabular}{cccc}
$1 \mathrm{G}$ & $2 \mathrm{~S}$ & $3 \mathrm{~S}$ & $4 \mathrm{~S}$ \\
\hline 100.0 & 66.0 & 52.0 & 1.0
\end{tabular}

Per Cent Population Reduction

$\longrightarrow$

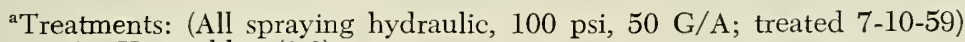

1. Heptachlor (1.0)

2. Thiodan (0.5)

3. Malathion (1.25)

4. Diazinon (0.5)

'Duncan's Multiple Range Test $(5.0$ per cent level) for $\log (N+1)$ of the data; treatments sharing a line in common do not differ in effectiveness. 
The same observations were true in Site 2 (Table 6A); Thiodan (0.5) spray gave the best results, but they were not satisfactory.

1961 (Table 6B). The plots in Site 3 treated with fenthion (1.0) and carbaryl (1.0) sprays gave the best, but inadequate, reduction in the numbers of spittlebug adults one week after treatment. Two weeks after treatment, carbaryl (1.0) and Zectran (0.75) sprays were most effective, but not adequate, in reducing the numbers of adult spittlebugs.

\section{DISCUSSION}

Leafhopper Control. A number of treatments were effective in controlling leafhoppers for as long as two weeks. Included in this group were

TABLE 4B

Experimental Control of Grasshoppers (1959-1962)

\begin{tabular}{|c|c|c|c|c|c|c|c|c|c|}
\hline \multirow{3}{*}{$\begin{array}{l}\text { Treatments } \\
\text { Per Cent } \\
\text { Pop. Reduction }\end{array}$} & \multicolumn{7}{|c|}{$\begin{array}{c}\text { Site } 3 \text { (Plots } 1 / 8 \text { A x 2) } \\
\text { Coll. 7-18-61, Av. No. Untrt'd. 22/25 Sweeps) }\end{array}$} & \multirow[b]{2}{*}{$8 \mathrm{~S}$} & \multirow[b]{2}{*}{$9 S$} \\
\hline & 1S & $2 \mathrm{~S}$ & $3 S$ & $4 \mathrm{~S}$ & $5 S$ & $6 \mathrm{~S}$ & $7 \mathrm{~S}$ & & \\
\hline & 100.0 & 100.0 & 100.0 & 100.0 & 100.0 & 100.0 & 100.0 & 79.0 & 73.0 \\
\hline \multicolumn{9}{|c|}{ (Coll. 7-25-61, Av. No. Untrt'd. 33) } & \\
\hline Treatments & $6 \mathrm{~S}$ & $2 S$ & $7 \mathrm{~S}$ & 1S & $9 S$ & $3 S$ & $5 S$ & $8 \mathrm{~S}$ & $4 \mathrm{~S}$ \\
\hline $\begin{array}{l}\text { Per Cent } \\
\text { Pop. Reduction }\end{array}$ & 84.0 & 75.0 & 73.0 & 67.0 & 67.0 & 61.0 & 57.0 & 52.0 & 35.0 \\
\hline \multicolumn{10}{|c|}{ (Coll. 8-1-61, Av. No. Untrt'd. 62) } \\
\hline Treatments & $7 \mathrm{~S}$ & $2 S$ & $9 \mathrm{~S}$ & $3 S$ & $1 S$ & $6 \mathrm{~S}$ & $4 \mathrm{~S}$ & $5 S$ & $8 S$ \\
\hline $\begin{array}{l}\text { Per Cent } \\
\text { Pop. Reduction }\end{array}$ & 62.0 & 58.0 & 56.0 & 48.0 & 48.0 & 35.0 & 30.0 & 29.0 & 23.0 \\
\hline
\end{tabular}

${ }^{\mathrm{a}}$ Treatments: (All spraying hydraulic, $125 \mathrm{psi}, 45 \mathrm{G} / \mathrm{A}$; treated 7-11-61)

1. Malathion (1.0)

2. Diazinon (0.75)

3. Fenthion (1.0)

4. Phosphamidon $(0.25)$

5. Zectran $(0.75)$

6. Cynem (1.5)

7. Cynem $(3.0)$

8. Carbaryl (1.0)

9. Trichlorfon (1.0)

${ }^{b}$ Duncan's Multiple Range Test (5.0 per cent level) for $\log (\mathrm{N}+1)$ of the data; treatments sharing a line in common do not differ in effectiveness. 
Experimental Control of Grasshoppers (1959-1962)

Site 4 (Plots $1 / 16 \mathrm{~A} \times 2$ )

(Coll. 8-8-62, Av. No. Untrt'd. 38/25)

Treatments ${ }^{\mathrm{a}}$

Per Cent Pop. Reduction ${ }^{\mathbf{b}}$

\begin{tabular}{ccccccccr}
$1 \mathrm{~S}$ & $2 \mathrm{~S}$ & $3 \mathrm{~S}$ & $4 \mathrm{~S}$ & $5 \mathrm{~S}$ & $6 \mathrm{~S}$ & $7 \mathrm{~S}$ & $8 \mathrm{~S}$ & $9 \mathrm{~S}$ \\
\hline 90.0 & 82.0 & 82.0 & 76.0 & 76.0 & 68.0 & 65.0 & 62.0 & 0.0
\end{tabular}

(Coll. 8-15-62, Av. No. Untrt'd. 28)

Treatments

Per Cent Pop. Reduction

\begin{tabular}{ccccccccc}
$1 \mathrm{~S}$ & $6 \mathrm{~S}$ & $7 \mathrm{~S}$ & $8 \mathrm{~S}$ & $4 \mathrm{~S}$ & $2 \mathrm{~S}$ & $5 \mathrm{~S}$ & $3 \mathrm{~S}$ & $9 \mathrm{~S}$ \\
\hline 67.0 & 62.0 & 54.0 & 54.0 & 50.0 & 50.0 & 42.0 & 37.0 & 0.0
\end{tabular}

(Coll. 8-22-62, Av. No. Untrt'd. 30)

Treatments

Per Cent Pop. Reduction

\begin{tabular}{ccccccccc}
$7 \mathrm{~S}$ & $1 \mathrm{~S}$ & $8 \mathrm{~S}$ & $2 \mathrm{~S}$ & $5 \mathrm{~S}$ & $6 \mathrm{~S}$ & $4 \mathrm{~S}$ & $3 \mathrm{~S}$ & $9 \mathrm{~S}$ \\
\hline 63.0 & 62.0 & 53.0 & 46.0 & 43.0 & 30.0 & 26.0 & 23.0 & 0.0
\end{tabular}

${ }^{a}$ Treatments: (All spraying hydraulic, 175 psi, $27 \mathrm{G} / \mathrm{A}$; treated 8-1-62)

1. Amer. Cyan. $\$ 43064(0.5)$

2. Azinphosmethyl (0.5)

3. Ciodrin (0.8)

4. Dimethoate $(0.5)$

5. Telodrin (1.0)

6. Malathion (1.0)

7. Cynem (1.0)

8. Diazinon $(0.75)$

9. Lindane $(0.5)$

'Duncan's Multiple Range Test (5.0 per cent level) for Log $(N+1)$ of the data; treatments sharing a line in common do not differ in effectiveness.

malathion (1.0), cynem (1.0), Ciodrin (1.0) (0.8), lindane (0.5), dimethoate (0.5), azinphosmethyl (0.5) (0.75) and diazinon (0.75) sprays. Some treatments were effective for three weeks post-treatment including malathion (2.0), Telodrin (0.25), and azinphosmethyl (0.75) sprays. Among the October treatments only methyl-ethyl azinphosmethyl (1.0) and phorate (1.0) granules showed any appreciable effect against aphids the following May.

Wolfenbarger (1963), Forsythe et al. (1962), and Eckenrode and Ditman (1963) also obtained satisfactory leafhopper reductions using dimethoate spray applications.

Plant Bug Control-Several of the insecticides provided satisfactory control of plant bugs. Malathion (1.25) spray gave excellent control for four weeks in one site and phorate (1.0) granules provided good control for the same length of time. Telodrin (2.5) granules and malathion (1.0) 


\section{Experimental Control of Grasshoppers (1959-1962)}

\begin{tabular}{|c|c|c|c|c|c|c|c|c|c|c|}
\hline \multicolumn{11}{|c|}{$\begin{aligned} \text { Site } 5 \text { (Plots 1/16A x 2) } \\
\text { (Coll. 8-8-63, Av. No. Untrt'd. 369/25 Sweeps) }\end{aligned}$} \\
\hline Treatments & $1 S$ & $2 S$ & $3 S$ & $4 S$ & $5 S$ & $6 S$ & $7 \mathrm{~S}$ & $8 S$ & $9 \mathrm{~S}$ & $10 \mathrm{~S}$ \\
\hline $\begin{array}{l}\text { Per Cent } \\
\text { Pop. Reduction }\end{array}$ & 91.0 & 88.0 & 88.0 & 71.0 & 70.0 & 62.0 & 56.0 & 56.0 & 27.0 & 26.0 \\
\hline \multicolumn{11}{|c|}{ (Coll. 8-15-63, Av. No. Untrt'd. 154) } \\
\hline Treatments & $3 S$ & $4 \mathrm{~S}$ & IS & $2 S$ & $8 \mathrm{~S}$ & $7 \mathrm{~S}$ & $5 S$ & $6 S$ & $10 \mathrm{~S}$ & $9 \mathrm{~S}$ \\
\hline $\begin{array}{l}\text { Per Cent } \\
\text { Pop. Reduction }\end{array}$ & 100.0 & 80.0 & 76.0 & 72.0 & 60.0 & 57.0 & 54.0 & 47.0 & 20.0 & 20.0 \\
\hline
\end{tabular}

aTreatments: (All spraying hydraulic, $175 \mathrm{psi}, 27 \mathrm{G} / \mathrm{A}$; treated 8-1-63)

1. Amer. Cyan. $\$ 47031(0.75)$

2. Amer. Cyan. $\# 43064(0.75)$

3. Amer. Cyan. $\$ 47470(0.75)$

4. Dimethoate $(0.5)$

5. ME-Azinphosmethyl (0.5)

6. $\mathrm{SD}-8448(2.0)$

7. SD-4072 (1.0)

8. Malathion (1.0)

9. SD-8447 (1.0)

10. $\mathrm{SD}-8447(0.5)$

'Duncan's Multiple Range Test (5.0 per cent level) for Log $(\mathrm{N}+1)$ of the data; treatments sharing a line in common do not differ in effectiveness.

\section{TABLE 5}

\section{Experimental Control of Aphids (1960-1964)}

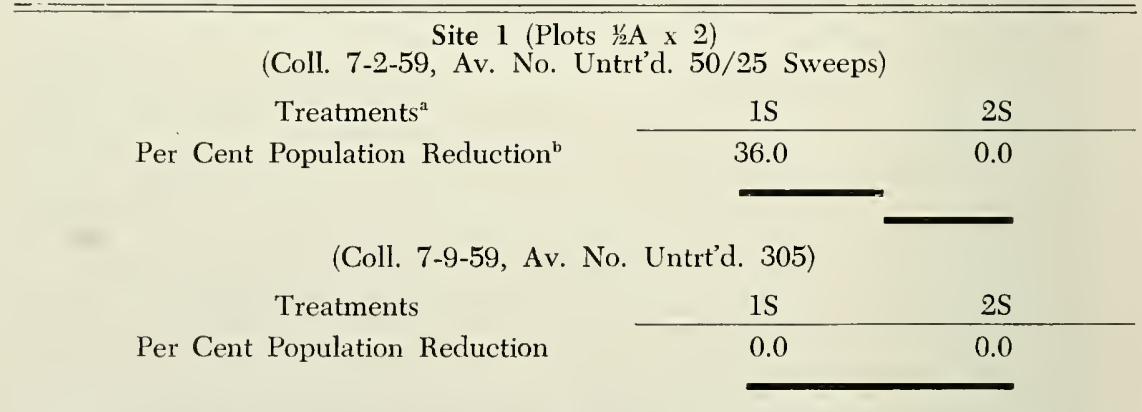

"Treatments: (All spraying hydraulic, $100 \mathrm{psi}, 50 \mathrm{G} / \mathrm{A}$; treated 4-23-60)

1. Malathion (1.0)

2. Diazinon (0.75)

'Duncan's Multiple Range Test (5.0 per cent level) for $\log (\mathrm{N}+1)$ of the data; treatments sharing a line in common do not differ in effectiveness. 
spray provided excellent control in another site. GS-13005 (0.5) and SD7438 (0.75 and 1.0) sprays and dimethoate (0.75) granules gave economic control for two weeks in one location and malathion (1.0), American Cyanamid 52160 (2.0) sprays, and dimethoate (0.75) granules provided three weeks control in another site.

\section{TABLE 5A}

\section{Experimental Control of Aphids (1960-1964)}

\begin{tabular}{|c|c|c|}
\hline \multicolumn{3}{|c|}{$\begin{aligned} & \text { Site } 2 \text { (Plots 1/8A x 2) } \\
& \text { (Col. 5-20-60, Av. No. Untrt'd. 22/25 Sweeps) }\end{aligned}$} \\
\hline Treatments ${ }^{\mathrm{a}}$ & 1S & $2 \mathrm{G}$ \\
\hline Per Cent Population Reduction ${ }^{\mathbf{b}}$ & 18.0 & 0.0 \\
\hline
\end{tabular}

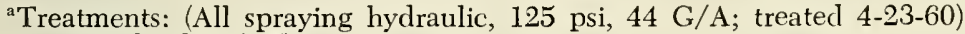

1. Thiodan (0.5)

2. Phorate $(1.0)$

'Duncan's Multiple Range Test (5.0 per cent level) for Log $(\mathrm{N}+1)$ of the data; treatments sharing a line in common do not differ in effectiveness.

\section{TABLE 5B}

\section{Experimental Control of Aphids (1960-1964)}

Site 3 (Plots $1 / 8 \mathrm{~A} \times 2$ )

(Coll. 7-18-61, Av. No. Untrt'd. 26/25 Sweeps)

Treatments ${ }^{\mathrm{a}}$

Per Cent Population Reduction ${ }^{\mathrm{b}}$

\begin{tabular}{cccc}
$1 S$ & $2 S$ & $3 S$ & $4 S$ \\
\hline 64.0 & 0.0 & 0.0 & 0.0
\end{tabular}

(Coll. 7-25-61, Av. No. Untrt'd. 3)

Treatments

Per Cent Population Reduction

\begin{tabular}{cccc}
$3 \mathrm{~S}$ & $4 \mathrm{~S}$ & $1 \mathrm{~S}$ & $2 \mathrm{~S}$ \\
\hline 29.0 & 0.0 & 0.0 & 0.0
\end{tabular}

(Coll. 8-1-61, Av. No. Untrt'd. 16)

Treatments

Per Cent Population Reduction

\begin{tabular}{crrr}
$4 \mathrm{~S}$ & $3 \mathrm{~S}$ & $2 \mathrm{~S}$ & $1 \mathrm{~S}$ \\
\hline 100.0 & 78.0 & 0.0 & 0.0
\end{tabular}

${ }^{a}$ Treatments: (All spraying hydraulic, $125 \mathrm{psi}, 45 \mathrm{G} / \mathrm{A}$; treated 7-11-61)

1. Zectran (0.75)

2. Malathion (1.0)

3. Cynem (1.50)

4. Cynem (3.00)

'Duncan's Multiple Range Test (5.0 per cent level) for Log $(\mathrm{N}+1)$ of the data; treatments sharing a line in common do not differ in effectiveness. 
Excellent plant bug control for one week was observed in one series of plots treated with cynem (1.5 and 3.0), Zectran (0.75), phosphamidon (0.25), fenthion (1.0), trichlorfon (1.0), and malathion (1.0) sprays.

Good plant bug control for one week was evident in another series of plots treated with Ciodrin (0.8), dimethoate (0.5), lindane (1.0), cynem (1.0), Telodrin (0.25), and American Cyanamid 43064 (0.5) sprays.

The only fall (10-14-63) treatments which gave economic control the following spring (5-6-64) were SD-8447 (2.0) and CP-50294 (1.0) sprays and methyl ethyl azinphosmethyl (1.0) granules.

TABLE 5C

Experimental Control of Aphids (1960-1964)

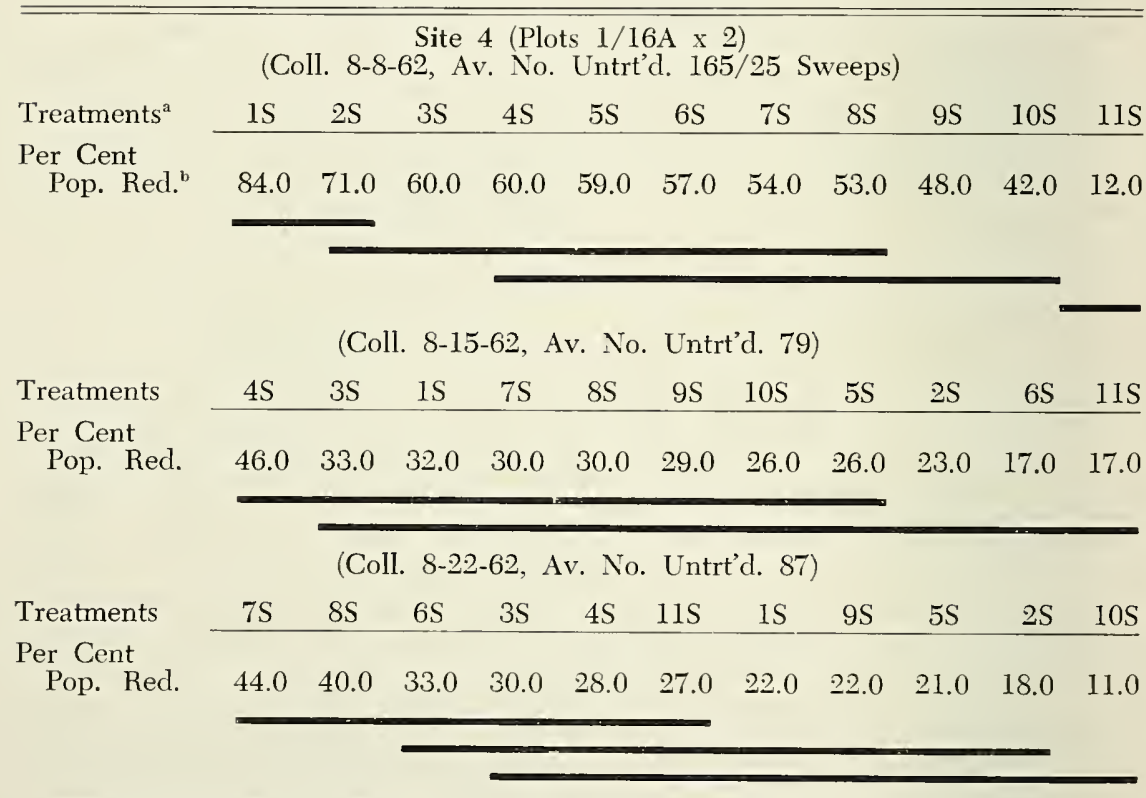

aTreatments: (All spraying hydraulic, $250 \mathrm{psi}, 27 \mathrm{G} / \mathrm{A}$; treated 8-1-62)

1. Ciodrin $(0.8)$

2. Imidan (0.5)

3. Cynem (1.0)

4. Malathion (1.0)

5. Diazinon $(0.75)$

6. Amer. Cyan. $\# 43064(0.5)$

7. Lindane $(0.5)$

8. Dimethoate $(0.5)$

9. Azinphosmethyl (0.5)

10. SD-7438 (1.0)

11. Telodrin $(0.25)$

'Duncan's Multiple Range Test (5.0 per cent level) for $\log (\mathbf{N}+1)$ of the data; treatments sharing a line in common do not differ in effectiveness. 
A mixture of malathion, plus toxaphene, gave Shorey et al. (1965) excellent plant bug control for several weeks. Fenton (1959) found malathion to be quite effective against both adult and nymphal stages of plant bugs (Lygus spp.). Koehler (1963) observed that dimethoate sprays gave better plant bug control than malathion, and Carlson (1961) reported dimethoate to be effective even for extended periods. Ridgway and Gyrisco (1960) determined that they could effectively control the tarnished plant bug for two weeks with a dimethoate spray. Phillips et al. (1961) and Pfimmer and Merkl (1962) obtained effective control of

lygus bugs with azinphosmethyl sprays. Davis et al. (1963) reported effective control of lygus bugs with dylox. Bottger and Sparks (1962) observed that Imidan, dimethoate, trichlorfon, and malathion gave equal or better control of a plant bug on cotton when compared with mixtures of chlorinated hydrocarbon insecticides.

\section{TABLE 5D}

\section{Experimental Control of Aphids (1960-1964)}

\begin{tabular}{|c|c|c|c|c|c|c|c|c|c|c|}
\hline \multirow{3}{*}{ Treatments ${ }^{\mathrm{a}}$} & 11. $8-8$ & $\begin{array}{l}\text { Site } 5 \\
63, \text { Ar }\end{array}$ & $\begin{array}{l}\text { (Plots } \\
\text { No. }\end{array}$ & $\begin{array}{c}1 / 16 \\
\text { Untrt' }\end{array}$ & $\begin{array}{l}\times 2 \\
27\end{array}$ & $5 \mathrm{Sw}$ & eps) & & & \\
\hline & IS & $2 \mathrm{~S}$ & $3 S$ & $4 \mathrm{~S}$ & $5 \mathrm{~S}$ & $6 \mathrm{~S}$ & $7 \mathrm{~S}$ & $8 S$ & $9 \mathrm{~S}$ & $10 \mathrm{~S}$ \\
\hline & 100.0 & 98.0 & 80.0 & 62.0 & 58.0 & 44.0 & 36.0 & 29.0 & 16.0 & 3.0 \\
\hline
\end{tabular}

(Coll. 8-15-63, Av. No. Untrt'd. 30)

Treatments

\begin{tabular}{cccccccccc}
$1 \mathrm{~S}$ & $2 \mathrm{~S}$ & $9 \mathrm{~S}$ & $4 \mathrm{~S}$ & $3 \mathrm{~S}$ & $6 \mathrm{~S}$ & $7 \mathrm{~S}$ & $5 \mathrm{~S}$ & $8 \mathrm{~S}$ & $10 \mathrm{~S}$ \\
\hline 50.0 & 39.0 & 34.0 & 18.0 & 14.0 & 9.0 & 9.0 & 0.0 & 0.0 & 0.0
\end{tabular}

Per Cent Pop. Red.

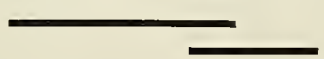

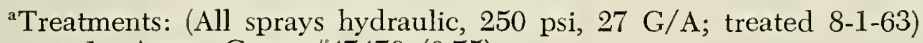

1. Amer. Cyan. $\# 47470(0.75)$

2. Dimethoate $(0.5)$

3. Amer. Cyan. \#43064 (0.75)

4. Diazinon (0.75)

5. ME-Azinphosmethyl (0.5)

6. SD-8447 (1.0)

7. Amer. Cyan. $\$ 47031(0.75)$

8. SD-8448 (2.0)

9. SD-4072 (1.0)

10. SD-8447 (0.5)

'Duncan's Multiple Range Test (5.0 per cent level) for $\log (\mathrm{N}+1)$ of the data; treatments sharing a line in common do not differ in effectiveness. 


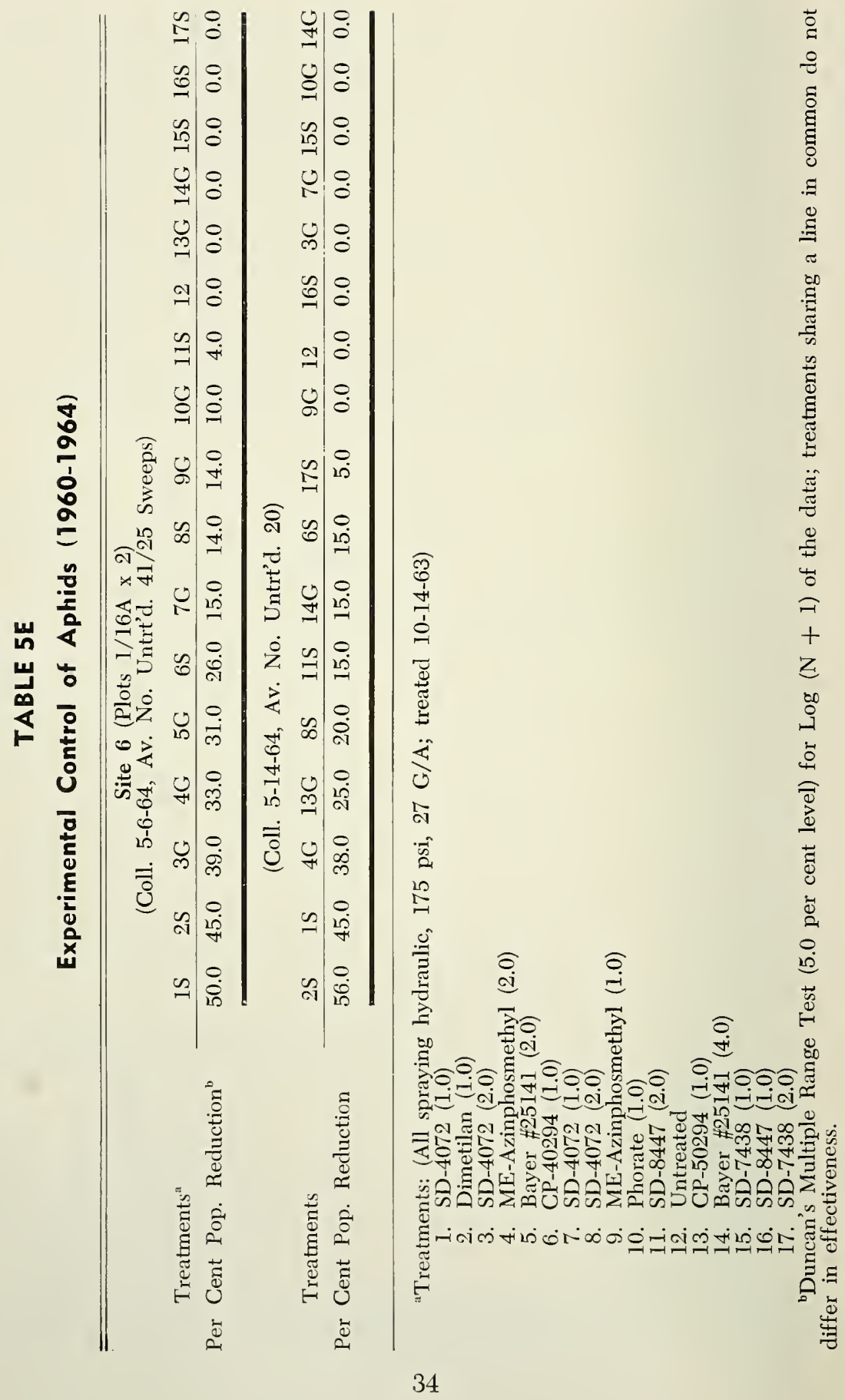




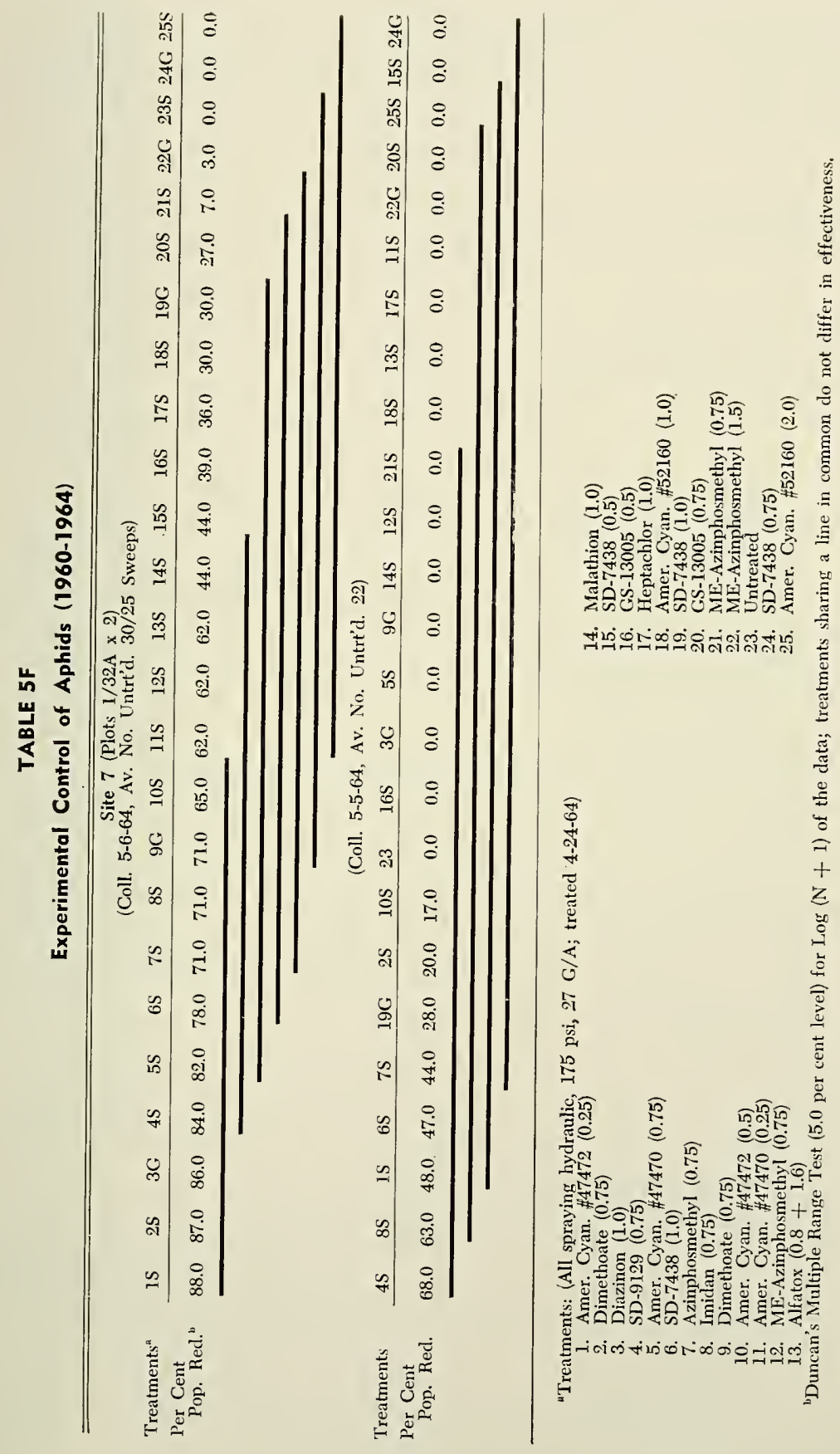


Grasshopper Control-Good to excellent control for one week was evident in plots treated with the following spray mixtures: Ciodrin (0.8), azinphosmethyl (0.5), trichlorfon (1.0), Telodrin (1.0), American Cyanamid $47031(0.75), 47470(0.75), 43064$ (0.5), carbaryl (1.0), cynem

\section{TABLE 6}

\section{Experimental Control of Meadow Spittlebug Adults (1959-1961)}

\section{Site 1 (Plots $1 / 2 \mathrm{~A} \times 2$ )}

(Coll. 7-2-59, Av. No. Untrt'd. 1610/25 Sweeps)

Treatments ${ }^{\mathrm{a}}$

Per Cent Population Reduction ${ }^{\mathrm{b}}$

\begin{tabular}{cccc}
$1 \mathrm{~S}$ & $2 \mathrm{G}$ & $3 \mathrm{~S}$ & $4 \mathrm{~S}$ \\
\hline 45.0 & 5.0 & 0.0 & 0.0
\end{tabular}

(Coll. 7-9-59, Av. No. Untrt'd. 721)

Treatments

Per Cent Population Reduction

\begin{tabular}{cccc}
$1 \mathrm{~S}$ & $3 \mathrm{~S}$ & $2 \mathrm{G}$ & $4 \mathrm{~S}$ \\
\hline 47.0 & 5.0 & 0.0 & 0.0 \\
\hline
\end{tabular}

areatments: (All spraying hydraulic, $100 \mathrm{psi}, 50 \mathrm{G} / \mathrm{A}$; treated 6-26-59)

1. Thiodan $(0.5)$

2. Heptachlor (1.0)

3. Diazinon $(0.5)$

4. Malathion (1.25)

bDuncan's Multiple Range Test (5.0 per cent level) for $\log (\mathrm{N}+1)$ of the data; treatments sharing a line in common do not differ in effectiveness.

\section{TABLE 6A}

\section{Experimental Control of Meadow Spittlebug Adults (1959-1961)}

\begin{tabular}{|c|c|c|c|c|c|}
\hline \multicolumn{6}{|c|}{$\begin{array}{l}\text { Site } 2 \text { (Plots } 1 / 2 A \text { x 2) } \\
\text { (Coll. 7-17-59, Av. No. Untrt'd. 2650/25 Sweeps) }\end{array}$} \\
\hline \multirow[b]{2}{*}{ Per Cent } & Treatments ${ }^{a}$ & 1S & $2 \mathrm{G}$ & $3 S$ & $4 S$ \\
\hline & Population Reduction ${ }^{\mathrm{b}}$ & 60.0 & 54.0 & 20.0 & 17.0 \\
\hline & (Coll. 7-2 & Av. N & 'd. 10 & & \\
\hline 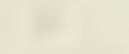 & Treatments & $1 S$ & $2 \mathrm{G}$ & $3 S$ & $4 \mathrm{~S}$ \\
\hline Per Cent & Population Reduction & 69.0 & 24.0 & 13.0 & 1.0 \\
\hline
\end{tabular}

${ }^{a}$ Treatments: (All spraying hydraulic, $100 \mathrm{psi}, 50 \mathrm{G} / \mathrm{A}$; treated 7-10-59)

1. Thiodan (0.5)

2. Heptachlor (1.0)

3. Malathion (1.25)

4. Diazinon (0.5)

${ }^{b}$ Duncan's Multiple Range Test (5.0 per cent level) for $\log (\mathrm{N}+1)$ of the data; treatments sharing a line in common do not differ in effectiveness. 
(1.5 and 3.0), Zectran (0.75), phosphamidon (0.25), fenthion (1.0), diazinon (0.5) (0.75), Thiodan (0.5), malathion (1.0) (1.25), dimethoate (0.5), and methyl ethyl azinphosmethyl (0.5).

Good to fair control for two weeks was observed in plots treated with cynem ( 1.5 and 3.0), diazinon (0.75), malathion (1.0), and American Cyanamid 43064 (0.75) sprays.

Fair control for three weeks resulted from the use of spray mixtures of cynem (1.5 and 3.0), diazinon (0.75), trichlorfon (1.0), and American Cyanamid 43064 (0.75).

In one site, American Cyanamid 47470 (0.75) and 47031 (0.75) and dimethoate (0.5) sprays gave good to excellent control for two weeks.

Plots in another site treated with malathion (1.0) spray and heptachlor (1.0) granules also controlled grasshoppers in an excellent manner for two weeks.

Forsythe et al. (1962) found that dimethoate and azinphosmethyl sprays gave good grasshopper control. Skoog et al. (1961) reported that a number of different insecticides were promising for grasshopper control including diazinon, phosphamidon, carbaryl, dimethoate, and GC4072 sprays.

Aphid Control-Aphid control results were somewhat disappointing. American Cyanamid 47470 (0.75) spray gave excellent control for one

\section{TABLE 6B}

\section{Experimental Control of Meadow Spittlebug Adults (1959-1961)}

Site 3 (Plots $1 / 8 \mathrm{~A} \times 2$ )

(Coll. 7-18-61, Av. No. Untrt'd. 10/25 Sweeps)

Treatments ${ }^{\mathrm{a}}$

Per Cent Pop. Reduction ${ }^{\mathrm{b}}$

\begin{tabular}{ccccccc}
$1 \mathrm{~S}$ & $2 \mathrm{~S}$ & $3 \mathrm{~S}$ & $4 \mathrm{~S}$ & $5 \mathrm{~S}$ & $6 \mathrm{~S}$ & $7 \mathrm{~S}$ \\
\hline 35.0 & 30.0 & 0.0 & 0.0 & 0.0 & 0.0 & 0.0
\end{tabular}

(Coll. 7-25-61, Av. No. Untrt'd. 12)

Treatments

Per Cent Pop. Reduction

\begin{tabular}{ccccccc}
$2 \mathrm{~S}$ & $5 \mathrm{~S}$ & $6 \mathrm{~S}$ & $7 \mathrm{~S}$ & $1 \mathrm{~S}$ & $3 \mathrm{~S}$ & $4 \mathrm{~S}$ \\
\hline 20.0 & 20.0 & 13.0 & 0.0 & 0.0 & 0.0 & 0.0
\end{tabular}

aTreatments: (All spraying hydraulic, $125 \mathrm{psi}, 45 \mathrm{G} / \mathrm{A}$; treated 7-11-61)

1. Fenthion (1.0)

2. Carbaryl (1.0)

3. Trichlorfon (1:0)

4. Phosphamidon (0.25)

5. Zectran $(0.75)$

6. Diazinon $(0.75)$

7. Malathion (1.0)

'Duncan's Multiple Range Test (5.0 per cent level) for $\log (\mathrm{N}+1)$ of the data; treatments sharing a line in common do not differ in effectiveness. 
week. Fair to good control for two weeks was obtained with Ciodrin (0.8) and Zectran (0.75) sprays. Only fair control for two weeks was obtained with Zectran (0.75), malathion (1.0), and American Cyanamid $47470(0.75)$ sprays in another series of plots. In the plots of Site 7 aphid control results were confusing because of the small number of aphids present at the time of sampling. Good economic control was not evidenced by any treatment. American Cyanamid 47472 (0.25) and dimethoate (0.75) sprays and diazinon (1.0) granules gave the best control of all of the 24 treatments for two weeks, and the most effective treatments three weeks post-treatment were sprays of SD-9129 (0.75) and Imidan (0.75).

Reynolds and Anderson (1955) obtained excellent control of the spotted alfalfa aphid with malathion and diazinon sprays. Randolph (1956) reported excellent control of the pea aphid on alfalfa with malathion, as did Kerr and Stuckey (1956) on red clover. Jefferson et al. (1964) had excellent results using dimethoate granules against aphids on carnations.

Meadow Spittleburg Control-The control efforts in this study were directed against the adults of the meadow spittlebug. Fenthion (1.0), carbaryl (1.0), Thiodan (0.5), and Zectran (0.75) sprays looked more promising than some of the other insecticides for this purpose, although the results were not satisfactory. Possibly the dosage rates were too low.

Fahey et al. (1960) obtained effective spittlebug control with BHC, lindane and Thiodan sprays with rates as low as 0.25 .

Forsythe et al. (1960) observed the best control of adult spittlebugs after using endrin, lindane, Phosdrin, and azinphosmethyl sprays. Forsythe and Gyrisco (1962) reported excellent control with lindane and heptachlor granules. Hansen and Dorsey (1957) observed that both dieldrin and heptachlor granules, and heptachlor spray treatments in the spring provided excellent spittlebug control results. 


\section{LITERATURE CITED}

Daniels, N. E. 1955. Insects affecting alfalfa seed production. J. Econ. Entomol. $48(3): 339-40$.

Drake, C. J. 1948. Influence of insects on alfalfa seed production in Iowa. J. Econ. Entomol. $41(5) 742-50$.

Fahey, Jack E., M. Curtis Wilson and Harold W. Rusk. 1960. Persistence of BHC, lindane and thiodan residues when applied to alfalfa to control meadow spittlebug. J. Econ. Entomol. 53(5):960-1.

Forsythe, H. Y. and George G. Gyrisco. 1962. Evaluating control of the clover root curculio larvae on alfalfa. J. Econ. Entomol. 55(6):907-8.

Franklin, W. W. 1953. Insecticidal control plot tests for pea aphids in relation to alfalfa hay yields. J. Econ. Entomol. 46(3):462-7.

Hansen, H. L. and C. K. Dorsey. 1957. Meadow spittlebug control in West Virginia with granular insecticides. W. Va. Univ. Agr. Expt. Sta. Cir. 100, 2 pp.

Jeppson, L. R. and G. F. Macleod. 1946. Lygus bug injury and its effect on the growth of alfalfa. Hilgardia 17:165-84.

Johansen, C. 1960. Bee poisoning versus clover aphid control in red clover grown for seed. J. Econ. Entomol. 53(6):1012-5.

MacCollom, George B. 1958. Control of insects affecting birdsfoot trefoil seed production in Vermont. J. Econ. Entomol. 51 (4):492-4.

Medler, J. T. 1958. Seed production and certain growth characteristics of insect-free alfalfa. J. Econ. Entomol. 51(5):729-33.

Medler, J. T. and G. N. Brooks. 1957. Insect control in relation to alfalfa seed production in central Wisconsin. J. Econ. Entomol. 50(3):336-7.

Medler, J. T. and T. R. Chamberlain. 1948. Seed yields of red and ladino clovers increased by use of insecticides. J. Econ. Entomol. 41(1):108-9.

Medler, J. T. and J. M. Scholl. 1947. Control of insects affecting alfalfa seed production in Wisconsin. J. Econ. Entomol. 40(4):579-80.

Mittler, Tom E. and Edward S. Sylvester. 1961. A comparison of the injury to alfalfa by aphids, Therioaphis maculata and Macrosiphum pisi. J. Econ. Entomol, $54(4): 615-21$.

Romney, V. E., G. T. York and T. P. Cassidy. 1945. Effect of Lygus spp. on seed production and growth of guayule in California. J. Econ. Entomol. 38(1):45-51.

Schull, J. M. and J. T. Medler. 1947. Spittlebugs in relation to alfalfa seed production in Wisconsin. J. Econ. Entomol. 40(3):446-8.

Schull, W. E., P. L. Rice and H. F. Cline. 1934. Lygus hesperus Knight (Hemiptera. Miridae) in relation to plant growth, blossom drop and seed set in alfalfa. J Econ. Entomol. 27( 1$): 265-9$.

Smith, D. and J. T. Medler. 1959. Influence of leafhoppers on yield and chemical composition of alfalfa hay. Agron. Journ. 51(2):118-9.

Skoog, F. E., F. T. Cowan and R. V. Connin. 1961. Laboratory and field tests of new insecticides for grasshopper control. J. Econ. Entomol. 54(1):170-4.

Stitt, L. L. 1948. Reduction in vegetative growth of alfalfa by insects. J. Econ. Entomol. 41(5):749-841.

Weaver, C. R. and J. W. Hibbs. 1952. Effect of spittlebug infestation on nutritive value of alfalfa and red clover. J. Econ. Entomol. 45(4):626-8.

Weaver, M. C., R. T. Everly and D. L. Mathew. 1959. Infestation and damage done by the meadow spittlebug to alfalfa and clover in Indiana. Cooperative Econ. Insect Report 9(37):855-6.

Weaver, C. R. 1950. Improvement of hay yields resulting from control of meadow spittlebug. J. Econ. Entomol. 43( 1):7-11.

Wilson, M. C., R. L. Davis and G. G. Williams. 1955. Multiple effects of leafhopper infestation on irrigated and non-irrigated alfalfa. J. Econ. Entomol. 48(3):323-6. 



